IZA DP No. 10392

Growth with Equity:

Income Inequality in Vietnam, 2002-14

Dwayne Benjamin

Loren Brandt

Brian McCaig

November 2016 


\title{
Growth with Equity: Income Inequality in Vietnam, 2002-14
}

\author{
Dwayne Benjamin
}

University of Toronto

Loren Brandt

University of Toronto

and $I Z A$

Brian McCaig

Wilfrid Laurier University

\section{Discussion Paper No. 10392 \\ November 2016}

\author{
IZA \\ P.O. Box 7240 \\ 53072 Bonn \\ Germany \\ Phone: +49-228-3894-0 \\ Fax: +49-228-3894-180 \\ E-mail: iza@iza.org
}

Any opinions expressed here are those of the author(s) and not those of IZA. Research published in this series may include views on policy, but the institute itself takes no institutional policy positions. The IZA research network is committed to the IZA Guiding Principles of Research Integrity.

The Institute for the Study of Labor (IZA) in Bonn is a local and virtual international research center and a place of communication between science, politics and business. IZA is an independent nonprofit organization supported by Deutsche Post Foundation. The center is associated with the University of Bonn and offers a stimulating research environment through its international network, workshops and conferences, data service, project support, research visits and doctoral program. IZA engages in (i) original and internationally competitive research in all fields of labor economics, (ii) development of policy concepts, and (iii) dissemination of research results and concepts to the interested public.

IZA Discussion Papers often represent preliminary work and are circulated to encourage discussion. Citation of such a paper should account for its provisional character. A revised version may be available directly from the author. 


\section{ABSTRACT \\ Growth with Equity: Income Inequality in Vietnam, 2002-14}

We use the 2002 through 2014 Vietnam Household Living Standards Surveys to construct comparable measures of household income and estimates of income inequality over this high-growth period. We focus on two questions: How have benefits from growth been distributed; and do changes in the structure of the economy map into changes in inequality? We explore dimensions in which inequality may vary, notably urban versus rural, and by ethnic status. We also decompose inequality by income source to highlight key factors underlying the relatively low levels of inequality during this period. We find that agricultural opportunities played an important role in dampening inequality, but more important has been the steady development of wage-labor markets in both urban and rural areas. An important caveat to the generally rosy picture we paint is the deteriorating position of ethnic minorities. Finally, we draw comparisons with China and document key differences in their growthinequality experience.

JEL Classification: D31, D63, O53

Keywords: income inequality, Vietnam, decomposition

Corresponding author:

Brian McCaig

Department of Economics

Wilfrid Laurier University

75 University Avenue West

Waterloo, ON N2L 3C5

Canada

E-mail: bmccaig@wlu.ca

\footnotetext{
* We wish to thank Katherine Ziomek for her very helpful research assistance, Vu Hoang Dat for discussions concerning the household surveys, the editor, Stephen Jenkins, and two anonymous referees for helpful suggestions. Benjamin and Brandt also thank the Social Sciences and Humanities Research Council of Canada (SSHRC) for support. McCaig thanks the School of Business and Economics, Wilfrid Laurier University for support.
} 


\section{Introduction}

Vietnam is now well into its third decade of economic reform (Doi Moi). Since the start of the millennium, this process has benefitted from new injections of liberalization through major policy initiatives including the new Enterprise Law in 2000, the U.S.-Vietnam Bilateral Trade Agreement in 2001, and accession to the WTO in 2007. The latter two policies helped integrate Vietnam more tightly into the international economy, and contributed to rising inflows of FDI and a sharp increase in Vietnam's trade-to-GDP ratio. The effects of these policies are reflected in ongoing structural changes in the economy, and in the shift of GDP and labour out of agriculture and into manufacturing and services (see, e.g., Cling et al. (2009), and McCaig and Pavcnik (2013, 2014, 2015)). They have also been accompanied by sustained high rates of growth in the economy. Even with the slowdown of Vietnam's economy after 2008, first because of declining external demand, and a few years later, tightening monetary and fiscal policies, real GDP per capita grew at an annual rate of 5.3 percent. ${ }^{1}$

Our paper examines the distributive implications of these changes drawing on Vietnam's biennial household surveys from 2002 through 2014. The two guiding questions are:

- How have benefits from this growth been distributed through Vietnam's diverse population?

- Do the major changes in the structure of the economy map into changes in inequality?

From the outset of reforms, measuring and understanding the distributive consequences of economic reform was a high priority of the government of Vietnam, as well as international agencies like the World Bank. This helps explain the collection of household data starting in 1993, which followed the successful template of the World Bank's Living Standards Measurement Study. Thus, this paper is not the first to address these questions. There are excellent surveys of this research, most recently World Bank (2013), and a few key themes and patterns have emerged.

First, there has been a marked reduction in absolute poverty, though the rate of decline has slowed down since the mid-2000s (World Bank (2013), VASS (2006, 2011)). Some of the decline in poverty can also be specifically attributed to the liberalization of markets, as opposed to economic

\footnotetext{
${ }^{1}$ Based on our calculations using the World Bank's "World Development Indicators," described in Appendix B. See also Bhattacharya (2013) for a discussion of the macroeconomic policy environment over this period.
} 
growth more generally. ${ }^{2}$ Given that income levels are higher in cities than in rural areas, and the much larger size of the rural population, the vast majority of the poor live in the countryside. Persistent poverty is especially severe among Vietnam's ethnic minorities, which, given their geographic distribution, adds a strong regional dimension to poverty as well (World Bank (2013), Baulch, Hung, and Reilly (2012)). Second, since the early 1990s, consumption inequality has been relatively constant, moving within a fairly narrow range. Measures of income inequality are significantly higher than consumption-based measures, as is usually the case. Estimates suggest a sharp drop in income inequality in the 1990s, flattening off through the new millennium. ${ }^{3}$ Third, earlier income-based studies (e.g., Benjamin and Brandt (2004)) highlight the important role of robust growth in agricultural incomes in helping to moderate increases of inequality coming from other sources of income. They also identified the potentially disequalizing role of off-farm nonagricultural opportunities in the form of family-run businesses and wage earnings. Their results suggest that the ability of Vietnam to "grow with equity" in the context of significant structural change would depend on more equal access to non-agricultural opportunities.

Like the 2004 paper, we construct comparable measures of household income over time and use the changing composition of income to draw suggestive inferences on the relationship between economic structure and income inequality. There are several points of contrast between this paper and previous work that also studies the post-2000 period. ${ }^{4}$ Most of the other work, including World Bank (2013) focuses on consumption-based poverty, whereas we focus primarily on income growth and inequality. We construct household per capita income, spanning the period 2002 through 2014, which allows us to include evidence from the moderate slow-down that occurred in 2010. While we view the estimates of inequality themselves as substantively interesting, it is the decompositions of income inequality by source that yield the most important results in our paper. The decompositions allow us to identify the income sources, and thus markets, that

\footnotetext{
${ }^{2}$ For example, see Benjamin and Brandt (2004), Edmonds and Pavcnik (2006), and Coxhead, Vu and Le (2012) for studies pertaining to internal liberalization of markets (especially rice), and McCaig (2011) who explores connections between increased international trade and reductions of poverty.

${ }^{3}$ The first two waves of the Living Standards survey were conducted in 1993 and 1997, with a significant longitudinal (panel) dimension. The early studies are based on household consumption measured from these data, and include Glewwe, Gragnolati, and Zaman (2002), Glewwe (2004), and the other papers in that volume. Glewwe (2007) and Glewwe (2012) exploit the panel feature of these data to explore questions of distributional mobility between 1993 and 1997.

${ }^{4}$ This paper is a heavily updated and revised version of Benjamin, Brandt, and McCaig (2009), which is Chapter 2 of McCaig's PhD dissertation. Brandt was also involved in preparing the report, World Bank (2013), which builds on and extends these earlier studies including looking at issues that we do not address here.
} 
underlie Vietnam's particular experience of structural change, growth, and distribution of income. In addition, we provide a brief comparison with China over a comparable period in its development. Over a longer period, China has gone through a process similar in a number of respects to Vietnam's and achieved even faster rates of growth, but accompanied by remarkable increases of inequality. This comparison helps to highlight those margins on which Vietnam has done reasonably well. In numerous respects, Vietnam looks much more like Taiwan, Korea, or Japan.

Overall, we find a small decrease of income inequality in Vietnam, suggesting that growth has been accompanied by equity that extends beyond poverty reduction. There has been some increase of rural inequality, but in the aggregate, this is offset by declining urban-rural differences and declining inequality within urban areas. Less positively, increased rural inequality is driven primarily by slow income growth among ethnic minorities who represent a growing portion of the population. While the incomes of ethnic minorities rose over this period, they fell further behind the Kinh majority. Our decompositions yield two primary insights. First, farm incomes remain an important, relatively equalizing source of opportunity for rural households; and second, large segments of both the rural and urban populations are able to take advantage of new wageearnings opportunities. Furthermore, the growth of wage income we observe is driven more by rising earnings among those working for wages than simply increased participation in wage labour. This points to the labour market and its attendant linkages to human capital and education, as an important area of future research in better understanding how Vietnam has achieved "growth with equity" to this point.

\section{Estimation of Household Income}

Our research is based on a set of estimates of household per capita income, denoted $y_{i}$, that we calculate using the seven Vietnam Household Living Standards Surveys (VHLSS) conducted in even years from 2002-2014. Several conditions need to be satisfied before we can draw informative and reliable inferences. To begin, note that the underlying sampling unit is the household. The VHLSS defines household membership on the basis of physical presence: Individuals must eat and live with other members for at least six out of the past twelve months, and contribute to collective income and expenses. Among other things, this means that family members who have 
moved away to work or school (e.g., migrants) are not considered household members. Using these data, we calculate total household income, then divide by household size to create per capita income. As with consumption-based studies of inequality, the implicit assumption is that individual living standards are tied to overall household resources and that these are shared equally among household members. To mimic an individual-based income distribution, we weight the household data by household size.

The VHLSS surveys are stratified on the basis of geography, with the smallest unit of analysis being the commune. To reduce costs, the General Statistical Office (GSO) implements longer and shorter versions of the survey, with the longer survey including both income and consumption (expenditure) modules. We only use the smaller sample of households that were given the longer survey so that our income and expenditure estimates are drawn from the same sample of households. Moving up levels of aggregation, communes are a subset of districts, and districts are a subset of provinces. Provinces can further be aggregated into regions. The geographic structure of sampling was relatively consistent over our sample. The same communes are used from 2002 through 2008 (based on the 1999 Population and Housing Census), but based on the 2009 census, fresh communes were drawn for the surveys from 2010 onward (Phung and Nguyen (n.d.) and General Statistics Office (2008)). Because of the stratification of the survey by geography, we also use the sampling weights to obtain national representative summary statistics.

The surveys, and the income modules in particular, were conducted consistently over time. The reference period is almost always the last twelve months and the types of revenue-generating activities, along with their accompanying expenses, are defined consistently across the surveys. To better focus on the most important income sources, we divide annual household income into six major sub-aggregates: crop income; agricultural sideline income; non-farm business income; wage earnings; remittances (e.g., wages remitted from non-resident family members); and "other" sources (see Appendix A for further details).

Total household income is the sum of these six categories, and is designed to measure all observable income sources at the household's disposal for either consumption or saving. In order to make income comparable across space and time, especially so that it can be used as a measure of potential living standards, we convert all nominal incomes into nationally representative January 2012 prices using three sets of deflators. These pertain to survey month, survey year, and location. 
First, since the households within each survey year are interviewed during different months, we use the within-year monthly deflators that the GSO included in the datasets to convert the reported values to January prices of the respective survey year. This is an especially important exercise in high inflation years. Second, to link January prices of each respective survey year to January 2012, we utilize official GSO monthly CPI figures. And third, to reflect differences in the cost of living across regions we employ regional deflators based on Gibson et al. (2014).

Finally, in order to provide robust estimates of trends in inequality, we address the possibility that some of the most extreme measures of income are noise. Of course, it is impossible to know for certain whether any particularly large or small estimate of income is due to measurement error, or genuine differences in income. In our experience, however, at least some of these outliers are the result of measurement error that affects either revenue or costs. To account for this possibility, we trim the top and bottom tails of the distribution. Specifically, we drop observations in the bottom one percent of either the individual income or consumption distribution, and households with values greater than fifteen times the median for either individual income or consumption. All trimming rules are calculated separately by year, and for urban and rural areas. ${ }^{5}$ Trimming drops less than 2 percent of observations. In Appendix A, we report the core results of our paper using the untrimmed sample. The bottom line is that although the levels of inequality are slightly reduced by trimming, overall trends and patterns are unaffected.

To aid in interpreting the income levels reported below, as our empirical results are reported in thousands of constant 2012 VND, a reported estimate of " 7,311 " is worth about $\$ 1,000$ USD in PPP terms. ${ }^{6}$

\section{Results}

\subsection{Growth and the evolution of inequality}

The top panel of Table 1 provides estimates of average per capita income and consumption for 2002 through 2014. For each measure, we also calculate the implied average growth rate, using 2002 and

\footnotetext{
${ }^{5}$ See, for example, Cowell, Litchfield, and Mercader-Prats (1999), for a discussion of the robustness of conclusions concerning trends in inequality to different strategies for dealing with "dirty data."

${ }^{6}$ See World Bank International Comparison Program, http://data.worldbank.org/indicator/PA.NUS.PPP, accessed March 17, 2015.
} 
2014 as endpoints. Overall growth in household per capita income was an impressive 6.9 percent per year. By 2014, per capita household income was 25.8 million VND, or about $\$ 3,535$ USD per capita in PPP terms. For comparison, we also report GSO/World Bank consumption estimates based on the same VHLSS surveys. Per capita consumption increased commensurately with our estimates for income, growing an average 8.0 percent per annum. In Appendix B we compare the growth rates based on the VHLSS to measures from the National Income and Expenditure Accounts: The patterns are similar.

Turning to inequality, we show estimated inequality using the Gini coefficient and Theil index in the lower panel of Table 1. In the first row we report the Gini coefficients for income, which started at 0.375 in 2002, rose in 2008 and 2010, and then fell back to 0.360 in 2014 . Over the twelve year period, the Gini fell by 0.015. The standard error of the difference between 2014 and 2002 is approximately 0.004 , suggesting that the decrease is statistically significant. The Gini's for per capita consumption are shown in the next row for comparison. As is typical, consumption is less unequally distributed than income. The trend, however, is similar: Inequality rises modestly from 0.342 in 2002 to 0.380 in 2010, and then falls to 0.336 in 2014. The Theil index estimates for both income and consumption mirror the pattern of the Gini.

By their nature, estimates of inequality are summary statistics of the entire distribution of income and may hide important changes in the distribution. As such, we present two ways of visualizing the change in the entire income distribution. Figure 1 shows mean incomes by year for key percentiles of the income distribution: 90th, 75th, 50th, 25th, and 10th. For each percentile, we also show the implied average rate of growth of incomes between 2002 and 2014. The most important point to note is the solid growth throughout the distribution over this period: Even the bottom decile experienced 5.8 percent average growth, which is likely to be reflected in significant reductions in poverty. Growth rates are generally higher as one moves up the percentiles. The growth rate of the median was fastest, at 7.7 percent per year, while growth at the 90th percentile was slightly lower at 6.7 percent. The decline in the Gini and Theil indices is due to the middle of the distribution catching up slightly with the upper end of the distribution, which offsets the slower growth of the poorest households in the 25 th percentile and lower.

This pattern is confirmed in Figure 2a, which shows the Lorenz curves for the endpoint years, 2002 and 2014. Does a clear picture of changes in inequality emerge? The Lorenz curve for 2014 
is below that for 2002 until approximately the 40th percentile, after which it lies above. Figure $2 \mathrm{~b}$ shows the difference in Lorenz curves for the two years more clearly, with the $95 \%$ confidence interval. It is easier to see that inequality increased in the bottom of the distribution, but decreased in the upper half of the distribution, consistent with Figure 1. Inequality indices that put a greater weight on inequality at the bottom of the distribution may not show the same decline in inequality as measured by the Gini coefficient and the Theil index.

\subsection{Spatial dimensions of inequality}

Location is an important determinant of inequality in many countries. Thus, in Table 2 we explore the role of location for explaining levels of inequality between 2002 and 2014. In the first row, we report the percentage of households classified as urban, which increased from 22.7 percent to 31.4 percent, an increase of almost 9 percentage points. This represents an increase of over one-third in the level of urbanization. Some of this is due to migration from country to city, but also arises as previously rural areas develop and are reclassified as urban status. This is important to bear in mind as we compare differences in income between rural and urban areas over time: urban and rural status is not an immutable geographic characteristic, but is correlated with economic development. That said, over the time period we study, Vietnam is almost three-quarters rural. Consequently, as a matter of both arithmetic and economics, much of what happens overall is driven by results in the countryside.

In 2002, rural incomes were 9.6 million VND (i.e, 9,562 thousand VND in the tables), and more than doubled in real terms to 22.5 million VND in 2014. The implied annual growth rate was over seven percent. Urban incomes also grew at an impressive pace of 5.4 percent per year, but notably slower than in the countryside. In 2002, urban incomes were 1.8 times higher than rural incomes, but with faster rural growth, the urban-rural ratio fell only to 1.5 by 2014 . Hence, the diminishing urban-rural gap is one contributing factor to the decline in national inequality.

In Table 2, we also show estimated inequality using the Gini and Theil indices for rural and urban samples. The rural Gini starts at 0.341 in 2002 and rises steadily to 0.375 in 2012 , before falling slightly in 2014 to 0.365 . Over the period, the net effect was an increase of 0.025 . The standard error of the difference between the 2014 and 2002 Gini's is approximately 0.005, suggesting that the increase in the Gini is statistically significant. The Theil index for rural income inequality 
(not surprisingly) mirrors the pattern of the Gini (See Appendix A for further details on the evolution of rural and urban incomes across the distribution).

For urban Vietnam, the pattern is reversed, with the Gini dropping from 0.365 to 0.313 . With a standard error of 0.008 , the decline is statistically significant. Note, however, that there was a rise in inequality in 2008 and 2010, before the declines in 2012 and 2014. Again, the Theil index shows a similar pattern to the Gini coefficient, in this case, a decline over the period. The fall in urban inequality helped contribute to the decline in overall inequality.

How much inequality arises from variation of economic opportunity across locations? Is inequality becoming more or less local? To address these questions, we formally decompose the Theil index of inequality into that part attributed to differences of income between locations, and that part due to differences among households within a location. In the bottom panel of Table 2, we show results of this decomposition, beginning with location defined as rural versus urban. In relative terms, the contribution to the Theil index of the "between" urban and rural component, that is, the difference in average income between the two, fell consistently over time: The urban-rural gap accounted for 14.4 percent of the Theil in 2002, but only only 7.6 percent in 2014 . Thus, inequality is increasingly within rural and urban areas, not between them. Moving to a finer measure of location - being in one of 60 provinces - the relative contribution of location to Theil-measured inequality also fell by half, from 20.7 percent in 2002 to 10.3 percent in 2014 . Lastly, we define location based on urban/rural within-provinces. Again, income differences between locations have become less important in accounting for inequality: inequality is increasingly a within-location outcome. This means, for example, that households in cities outside major development poles like Hanoi and Ho Chi Minh City are catching up. Indeed, FDI is likely helping spread development beyond the two largest, and historically most important cities. This happens directly, as well as through the channel of migration. ${ }^{7}$

\subsection{Ethnic Minorities and Inequality}

As noted by Baulch and $\mathrm{Vu}$ (2011) and World Bank (2013), ethnic minorities are a key subpopulation that is distinctly over-represented in poverty, and left behind in the development pro-

\footnotetext{
${ }^{7}$ McCaig and Pavcnik (2015) report that among manufacturing workers in 2009, over 25 percent of the youngest workers (aged 20-24) had migrated across provincial boundaries. For further discussions of the links between migration and inter-provincial income differences, see Fukase (2013) and Diep and Coxhead (2010).
} 
cess. To explore this further, in Table 3, we look more closely at the rural income distribution (where ethnic minorities live), separating minority households from the ethnic majority (mostly) Kinh. The results are striking, and consistent with previous research on the tenuous, and deteriorating position of ethnic minority households (see World Bank (2013) for an excellent list of references, as well as Baulch, Hung and Reilly (2012), van de Walle and Gunewardena (2001), and van de Walle and Cratty (2004)). First, note that the share of minorities in the rural population is rising over time, from below 15 percent in 2002 to over 18 percent in 2014 . This is a consequence of higher fertility among minorities, combined with rising urbanization among the Kinh. Average incomes of the Kinh households rose by 7.5 percent over the period, while minorities experienced a respectable, but significantly lower growth rate of 5.7 percent. The ratio of Kinh to minority incomes thus rose from 1.64 in 2002, to more than 2.00 by 2014. At least some of the increase in rural inequality can therefore be pinned on the rising Kinh-minority income gap.

This can also be seen by the increasing concentration of ethnic minorities in the bottom decile of the rural income distribution, which we show this in two ways. First, we report the percentage of ethnic minorities that are in the bottom decile. This rose from 25.2 percent in 2002 to 35.6 percent in 2014, an increase of more than ten percentage points. In conjunction with their rising share of the rural population, this means that ethnic minorities make up a larger share of the bottom decile. In 2002, ethnic minorities accounted for about a third (36.9 percent) of individuals in the bottom decile. By 2014, this doubled to two-thirds (65.0 percent). Low income has a pronounced ethnic dimension.

Just as interestingly, inequality has risen rapidly among ethnic minorities, from a Gini of 0.294 in 2002 to 0.388 in 2014. The Theil index increases similarly rapidly. While inequality increased among rural Kinh from 2002 to 2012, it fell back in 2014 to essentially the same level as in 2002. This is true for both the Gini and Theil. Hence, the rise in rural inequality is due to the growing Kinh-minority gap combined with inequality among minorities. A subset of minority households is thus doing especially poorly, while others are better able to participate in the broader growth in rural areas. As a final exercise, we decompose the Theil index into within and between components for minorities and Kinh. The between ethnic-group contribution doubled from 5.8 percent of rural inequality in 2002 to 11.7 percent in 2014. Given the significant size of the minority population, an important part of the rise of inequality in the countryside can thus be attributed to issues 
pertaining to the integration of these minorities in the development process.

\subsection{Structure of income}

We now turn to identifying changes in economic structure, as reflected in the composition of income, that may help explain these patterns of inequality. Table 4 summarizes the composition of income by source. In the top panel, we report mean income from each source for the endpoint years 2002 and 2014, the implied annual average growth rates over the period, and the share of total income coming from each source in the end years. In the bottom panel we break down the overall averages into the mean conditional on positive, and the share of households participating in a given activity. The rationale for doing so is straightforward. Mean household per capita income in each activity is influenced by two margins: the share of households that participate in the activity (the extensive margin), and the amount of income generated by each participating household (the intensive margin). As a result of structural change in the economy, changes at the extensive margin will give rise to differences in the average growth rate in an income source calculated over all households, compared to only over households earning income from that source. This distinction will be useful when we decompose inequality by income source later on.

In 2002, income from farming, i.e. cropping and agricultural sidelines, was a major source of total income, accounting for 30.6 percent of total household income. Despite the largely rural nature of the economy, income-earning opportunities were more important outside of farming. More than half of all households had family members earning wage income, which was the source of 30.5 percent of all income. As remittances are generally wages earned elsewhere, wages and remittances combined accounted for more than a third of household income. Family businesses, on the other hand, contributed 23.0 percent to total income, with 41.0 percent of all households running at least one family business.

Changes in the structure of the rural economy between 2002 and 2014 are reflected in the growth rates by income source. Especially noteworthy are new labor market opportunities in industry and services, which contributed to rapid growth of wage earnings of 9.6 percent per year. Income from family businesses also grew rapidly, increasing by 6.6 percent per year. As expected, income growth in agriculture lagged, but even with the shock to incomes after 2008 caused by falling global farm prices, growth in crop incomes still averaged a respectable 3.3 percent over the 
full period, and sidelines mustered 3.6 percent growth. Some of this slow growth reflects the decline in participation in agriculture, which fell from 71.5 percent, to 60.9 percent over the period. (See Appendix A for a detailed comparison of urban and rural income structure).

Cumulatively, these shifts contributed to marked changes in the composition of income. By 2014, wages represented 42 percent of household income-an increase of 10 percentage points. Wages and and remittances combined were almost half of total income. ${ }^{8}$ This increase came at the expense of farming, and in 2014, cropping and agricultural sidelines contributed only 20.2 percent to average per household incomes compared to 30.6 percent in 2002. Participation in familyrun businesses declined, but this was offset by growth on the intensive margin, which helped to maintain family business's share of income at 22.3 percent of household income.

\subsection{Inequality and the structure of income}

One of the primary advantages of using income data to analyze inequality is that it permits studying the underlying sources of levels and changes in inequality that can be linked to the structure of the economy. While it is not possible to attribute "causality" to these factors, decompositions of income by source are informative in identifying key markets that merit further study in better understanding the causes of inequality (e.g., Jenkins (1995)). In the case of Vietnam, we have described the growing importance of wage income in both rural and urban areas: To what extent has the labor market contributed to the inequality outcomes observed? We conduct two types of decomposition:

- A Shorrocks (1982) decomposition that is valid for any inequality index; and

- An accounting of the Gini coefficient, following the procedure described in Lerman and Yitzhaki (1985).

\section{The Shorrocks Decomposition}

The Shorrocks decomposition estimates the proportion of total inequality that can be attributed to a particular income source, independent of the inequality index used. Consider a decomposition

\footnotetext{
${ }^{8}$ In a separate analysis we used the individual-level data to explore patterns of wage-labour participation by age, education, and gender. The bottom line is that increased wage labour participation is widespread across all subgroups in rural areas. The only slight exception is slower participation growth for the declining share of individuals with less than completed primary education.
} 
of household $i^{\prime} s$ income according to $K$ income-generating activities:

$$
y_{i}=\sum_{k=1}^{K} y_{i k}
$$

Mean income can be written as the sum of mean income from each income source. A one percent increase in average income from source $k$ will lead to a $W_{k}$ percent increase in average total income, where $W_{k}$ is the share of income from source $k$. The decomposition of inequality proceeds in a similar manner. Let $Y$ denote the vector of total income across households, and $S_{k}(Y)$ denote the contribution of income type $k$ to total inequality, $I(Y)$ such that:

$$
I(Y)=\sum_{k=1}^{K} S_{k}(Y)
$$

The share, $s_{k}=S_{k}(Y) / I(Y)$, is the share of $I(Y)$ attributable to income from source $k$. Shorrocks demonstrated that for any inequality decomposition satisfying a set of desirable properties:

$$
s_{k}=\frac{\operatorname{cov}\left(y_{k}, y\right)}{\operatorname{var}(y)}
$$

which is independent of the inequality index, $I(Y)$. This also makes it clear that the contribution of an income source to overall inequality depends on its correlation with total income: income sources earned by the rich will be disequalizing, while income sources earned disproportionately by the poor will equalize incomes. How can $s_{k}$ be interpreted? Unlike the share of income earned from a particular source, $s_{k}$ can be negative. Thus, one interesting benchmark is zero. If $s_{k}$ is negative then the income source is disproportionately earned by the poor and a marginal increase in that income source, maintaining the same correlation with total income, would decrease overall inequality. In practice, very few sources of income will have a negative value of $s_{k}$, and thus a second helpful benchmark is the share of income earned from that activity, $W_{k}$. If $s_{k}>W_{k}$, then income source $k$ contributes more to inequality than it does to mean income, which we define as a disproportionate effect on inequality.

Another way to see the value of $W_{k}$ as a benchmark is to consider an economy where the rich and poor are identical, except that the rich have more money (as in the apocryphal exchange between Hemingway and Fitzgerald). If everyone earned their income the same way, so that 
income by source was simply scaled by $y_{i}$, then this could be described by $y_{i k}=W_{k} y_{i}+u_{i}$. The resulting Shorrocks decomposition would yield $s_{k}=W_{k}$. To the extent that income sources are disproportionately earned by the rich, we would estimate $s_{k}>W_{k}$.

As a matter of computation, $s_{k}$ can be estimated by the simple regression:

$$
y_{i k}=\alpha_{k}+\beta_{k} y_{i}+u_{i k}, \text { where } \hat{\beta}_{k}=\frac{\operatorname{cov}\left(y_{k}, y\right)}{\operatorname{var}(y)}
$$

This regression formulation makes clearer the interpretation of $s_{k}$. We are simply estimating the correlation of a particular source of income with total income. The regression framework also allows us to highlight the potential role of measurement error in skewing the estimated contribution of income source $k$ to overall inequality. Household business income, or even farm income, is subject to a considerable degree of measurement error. Unusually high income from a given source will thus feed into a high estimate of overall income. If genuine, the Shorrocks decomposition will correctly identify this as a disequalizing income source. However, if driven by measurement error, the role of this income source will be exaggerated, while the roles of the other sources will be downplayed (because the contributions sum to one).

A natural way to address this problem is to employ instrumental variables, using as an instrument some other measure of $y_{i}$ that does not suffer from the same measurement error. An excellent candidate is household consumption, $c_{i}$, which provides an alternative measure of a household's position in the total income distribution. The Shorrocks decomposition primarily highlights the correlation of income by source with position in the income distribution, and as long as there are no common error components, using $c_{i}$ essentially gives us a second "take" on this correlation. The IV estimator repackages this second, reduced-form "take" via the correlation of $c_{i}$ with $y_{i}$, and provides a consistent estimate of $s_{k}$. In the particular case of these household data, given that home-produced food enters both sides of the household balance sheet (i.e., both income and consumption), we use non-food expenditure, $\tilde{c}_{i}$, as our instrument.

We begin with a simple descriptive exercise in Table 5, summarizing the structure of income by quartile in 2002 and 2014. We report the share of total income from a given income source for each quartile group, where the quartiles are calculated using non-food consumption. From Table 4, we know that in 2002 crop income accounted for 20.2 percent of household income. In Table 5, we 
see that the share is much higher for poorer households, generating 39.7 percent of income for the bottom quartile group, and 23.6 percent for the second quartile group. For the top quartile group, crop income only counted for 9.7 percent. Clearly, crop income is more important for lower income households. In the last column, we report the difference in percentages of income accounted for by a given source between the top and bottom quartile group. A positive difference means that the income source is more important for the poor, while a negative sign signals income sources that are earned disproportionately by the rich. Family business income, for example, is earned disproportionately by the top quartile group. Wages, by comparison, are a more evenly distributed source of income across the quartiles, with a relatively smaller increase of 8.5 percentage points from the bottom quartile to the top quartile group. Remittances and other income are relatively evenly spread among the bottom three quartiles and then jump up for the fourth quartile group.

The general pattern is similar in 2014. For example, poor households continue to derive a larger share of income from crop income than richer households, but the gradient has decreased significantly as the bottom quartile group of households earn 24.8 percent of income from crops in 2014, as compared to 39.7 percent in 2002. Even more important is to note that in 2014, the share of income from wages is essentially flat across the quartiles, with the poorest quartile group now earning a slightly higher share than the richest quartile group. The only income source that has become more skewed toward the rich is "other income." Overall, the results presented in Table 5 suggest that the distribution of income sources across the distribution is uneven. Consequently, differences in growth rates and the distribution of growth of each income sources is likely to play a role in changing patterns of inequality.

\section{Decomposing the Gini}

A complementary approach is a decomposition of the Gini coefficient suggested by Lerman and Yitzhaki (1985). Let the Gini associated with the vector of household incomes, $Y$, be denoted $G(Y)$. Lerman and Yitzhaki show that $G(Y)$ can be decomposed as:

$$
G(Y)=\sum_{k=1}^{K} R_{k} G_{k} W_{k}
$$


where $R_{k}$ is the "Gini correlation" of income source $k$ with total income $y_{i}$, which is the ratio of the covariance of income source $k$ with the cumulative distribution of income and the covariance of income source $k$ with the cumulative distribution of income source $k ; G_{k}$ is the Gini coefficient of income source $y_{k}$; and $W_{k}$ is the share of income source $k$ in total income. We can thus estimate the contribution of source $k$ to the overall Gini as the product of these three factors, and dividing by $G(Y)$, we get another - different - estimate of $s_{k}$. With estimates of the three components, we can see whether an income source is highly disequalizing because:

1. It is disproportionately earned by the rich, $R_{k}$. This is analogous to the Shorrocks decomposition, in that it depends primarily on the correlation (the "Gini correlation") between income source $k$ and overall income. As with the Shorrocks, this correlation is subject to bias from measurement error. We will use the IV results from the Shorrocks decomposition to note where measurement error may be more important; or

2. The income source is itself unequally distributed, $G_{k}$. The Gini coefficient includes the "zeroes" for households who do not participate in income activity $k$, so changes in participation will lead to changes in $G_{k}$, as will changes in the distribution of $y_{k}$ conditional on positive; or

3. The income source is an important part of overall income, $W_{k}$.

Note that this decomposition does not satisfy the assumption of Two Factor Symmetry in Shorrocks (1982) and thus will produce different inequality shares.

\section{Results}

The results of these decomposition exercises are shown in Table 6, with the decomposition for 2002 and 2014 in the upper and lower panels respectively. Each panel reports: (1) The share of the income source, $W_{k}$, which is a useful benchmark for the Shorrocks, and a key part of the Gini decomposition; (2) the Shorrocks decomposition, first by OLS, and second by IV; and (3) the separate components of the Gini decomposition: the Gini Correlation, $R_{k}$, the Gini index of income source $k, G_{k}$; and the absolute and relative contributions of income source $k$ to the overall Gini coefficient. In the last column of the bottom panel, we report the change in these contributions 
between 2002 and 2014, which sum to the overall change in the Gini between 2002 and 2014 (the column labelled "Delta"). In addition to decompositions for each year, we therefore also have a decomposition of the changes in the Gini that can be accounted for by each income source.

In 2002, the Shorrocks decomposition identifies household business and wage income as the primary culprits in overall inequality. They account for over 70 percent of inequality for both the OLS and IV estimates. Note the striking difference between the IV and OLS estimates for household business and wage income. This is what we would expect if business income is measured with error. The OLS procedure exaggerates business' contribution to inequality, while the same measurement error understates the role of wage income. That said, the Shorrocks procedure (with IV) shows that while wage income accounts for 30.5 percent of income, it accounts for 42.5 percent of inequality. Remittance income is also important in generating more inequality than suggested by its share of income. Income from crops and agricultural sidelines are both relatively equalizing income sources as they account for a lower share of inequality than of income. The Gini decomposition also flags wage and household business income as being large contributors to overall inequality. They are both highly correlated with overall income $\left(R_{k}\right)$, and more unequally distributed than crop or agricultural sideline income. The Gini decomposition shows that remittances and other income are also highly correlated with overall income (similar magnitudes of $R_{k}$ as wage and business income) and highly unequal (large values of $G_{k}$ ), but their smaller share of overall income lowers their impact on overall inequality relative to wage and business income.

For 2014, wage income rises to 42 percent of total income. Again, the IV-estimated Shorrocks term is much higher than the OLS for wage income, suggesting that measurement error leads to an understated role of wage income in overall inequality. In contrast to 2002, the IV estimate suggests that the contribution of wages to inequality is the same as their share in mean income. As we saw in Table 5, this is consistent with wage income becoming equally important across the income distribution. The Gini coefficient of wage earnings is actually lower in 2014 than 2002 (0.605 versus 0.700$)$. With rising participation in the labor market, wage income is more prevalent and less unequally distributed, but it is still highly correlated with overall income, and thus an important contributor to overall inequality, as are remittances. Taken together, these results point to the central role of labor markets and wage opportunities as a key part of Vietnam's positive 
experience of inequality in the presence of high growth. ${ }^{9}$

\section{Discussion and Comparison to China}

China represents a potentially valuable basis of comparison for examining Vietnam's distributive record over the period we analyze. It neighbours Vietnam, and has gone through a similar transition from a closed, planned economy to one that is open, market-based and largely nonagricultural. A number of factors make this slightly difficult. First, there are obvious issues of comparability related to China's size, as well as important regional differences within China. In terms of population, China is fifteen times larger; in area, it is thirty times larger. Second, the two countries embarked on reforms at slightly different times and so finding periods that overlap in terms of the reform and development process becomes critical. Making things a bit easier is the fact that at the start of reform, the two countries were similar in many respects, most importantly, in low per capita incomes and in the relatively high percentage of the population living in the countryside. With the Chinese reforms beginning in the late 1970s, and Doi Moi a decade or so later, the period we analyze between 2002-2014 in Vietnam lines up reasonably well with the period running from the early 1990s to the early 2000s in China, or the decade running between Deng Xiaoping's famous Southern Tour and China's entry into the WTO. And third, there are problems of data comparability.

There are a number of alternative data sources and estimates of inequality for China that can be tapped for this comparison, albeit each with its own shortcomings. Since our purpose is more limited here, we will not dwell on these issues and simply take the estimates at face value. ${ }^{10}$ Fortunately, the estimates tell a fairly consistent story. In Table 7 we report a number of estimates for inequality for 1991 and 2001 for all of China and then for the urban and rural populations separately. To help put these numbers in context, in 1981, the first year for which we have estimates, the overall Gini for China was 0.31 , and 0.25 and 0.18 for rural and urban China, respectively. ${ }^{11}$

\footnotetext{
${ }^{9}$ Appendix A reports the inequality decomposition separately for the urban and rural samples.

${ }^{10}$ These issues including sampling, representativeness, definitions of household membership, price differences, etc. are taken up in Benjamin, Brandt, Giles, and Wang (2008). Some of these issues are also taken up in Li, Sato and Sicular (2013).

${ }^{11}$ These estimates suggest levels much lower than the earliest reported estimates for Vietnam using the 1992 VHLSS.
} 
By 1991, inequality in China was significantly higher than it was at the start of the reform, largely because widening differences among households within both rural and urban areas offset the benefits of a narrowing in the urban-rural gap. ${ }^{12}$ The overall level of inequality was also on par with our estimates for Vietnam in 2001. Over the next decade, inequality in China continued to rise, with the increase in the dispersion of incomes among households in the cities between 1991 and 2001 being larger than we observe in the Chinese countryside. The end of the iron rice bowl, and the massive layoffs from China's state-enterprise sector, and the growing wage dispersion in the cities linked to rising returns to human capital each figure prominently here. In the countryside, declining growth in farming incomes, and unequal access among rural households to emerging opportunities in the labor market and through family run businesses further skewed incomes. Much is often made of the role of regional differences in China's rising urban and rural inequality, but over this period geography actually became less, not more important, largely reflecting the liberalization of product and factor (labor) markets (Benjamin, Brandt, Giles, and Wang (2008)). Conservatively, the Gini for household per capita incomes for all of China in 2001 was in the vicinity of 0.45 .

China's huge size makes comparisons with Vietnam at the national level potentially misleading. In terms of population as well as area, Vietnam is much more comparable to a single province in China. In Table 7, we report estimates for a sample of urban and rural households drawn separately from coastal and interior provinces. The differences are stark. Although inequality increased in both regions between 1991 and 2001, we observe much smaller increases in the coastal provinces. Underlying this are two important features of growth in the coastal provinces: first, there was basically no rise in rural inequality, and second, there was more rapid growth in rural than urban incomes, and thus there was a decline in the urban-rural gap. By contrast, in the interior provinces, urban, rural as well as urban-rural differences all increased significantly between 1991 and 2001, while income growth lagged that in the more dynamic coastal provinces.

In key respects, Vietnam's distributive record has similarities with that of China's more open and rapidly growing provinces, especially in regards to the behaviour of rural incomes. And here, the ability of rural households to access off-farm opportunities, especially through the labor market

\footnotetext{
${ }^{12}$ This narrowing reflects the huge gains from early reforms that were focused on the rural sector and contributed to rapid growth in agriculture and local non-agricultural sources of income.
} 
and in SMEs, has been important, as has been the ability of those remaining in agriculture to shift into more highly valued crops. No one policy in these provinces can be singled out, but lower barriers to entry for new firms, an openness to FDI, as well as fewer restrictions on individual mobility are all likely important.

More recent estimates for China suggest a continued rise in inequality with levels now between 0.50-0.55 (See for example Xie and Zhou (2014)). ${ }^{13}$ As both countries continue to develop, one of the striking comparisons is with the labor market, and the role of wage earnings in inequality. In Vietnam, as we illustrate in this paper, access to the labour market and wage earnings have been an important reason why growth has been relatively equitable. By contrast, in China, inequality in wage earnings has increased significantly, largely as a result of widening differences in educational attainment and a sharp rise in the premium to higher levels of education, especially at the university level (Park, Song, Zhang, and Zhao (2005)). This may eventually occur in Vietnam as well, but the existing differences in the labour market outcomes highlight the important interactions between education policy, the development of off-farm opportunities, and distributive outcomes.

\section{Conclusions}

Given the significant structural changes and high rate of growth over this period, it is remarkable how little inequality has changed. Overall inequality declined slightly from a Gini of 0.375 in 2002 to 0.360 in 2014. Rural inequality rose relatively steadily, with the Gini rising from 0.341 to 0.365 , but urban inequality, on the other hand, actually declined from 0.365 to 0.313 . These offsetting trends, combined with a reduction of the gap between rural and urban incomes, account for the stability and slight decline of overall inequality.

Most of the rising rural income inequality derives from differences in outcomes between the Kinh majority and ethnic minorities. While it is true that incomes rose for minority households, they grew much slower than for Kinh. Moreover, amongst ethnic minorities, inequality itself rose more than among the Kinh. Understanding rural inequality dynamics therefore requires further research on the determinants of the livelihoods of minority households, especially as minorities are a rising share of the rural population. Here, our results about inequality are not all that

\footnotetext{
${ }^{13}$ See Knight (2014) for an overview of research on inequality in China, including a discussion of the various factors that have been suggested as underlying the growing, and high levels of current inequality.
} 
different from previous research with respect to poverty. Underlying the differences between Kinh and minorities, and also within the minority sub-population, are significant differences in access to higher paying earnings opportunities, in agriculture and the labour market.

The role of location in accounting for inequality has fallen dramatically. Specifically, inequality is increasingly a within-location outcome and less due to differences between locations. This is true between urban and rural areas, between provinces, and between urban and rural areas within provinces. Migration across locations has played a role in decreasing the importance of location for income.

Finally, the co-evolution of growth and relative equity in Vietnam is a sharp contrast with the experience of China, where there were much larger increases in inequality. In China, most of the overall increase of inequality is attributable to increases of inequality within rural and urban areas, arising from unequal access to new opportunities outside of agriculture. In rural areas, much slower growth of farm incomes for those for whom agriculture remains important, compounds these problems. While current policy matters, so do past policies that have influenced educational outcomes and the distribution of human capital in both the cities and the countryside. A promising research agenda would compare educational policies in the two countries to better understand the differential role played by returns to human capital in linking modernization, markets, and overall inequality.

\section{References}

Abdelkrim, Araar, and Jean Yves-Duclos. (2007). "DASP: Distributive Analysis Stata Package," PEP, World Bank, UNDP, Universite Laval.

Baulch, Bob and Vu Hoang Dat. (2011). "Poverty dynamics in Vietnam, 2002 to 2006," in Why poverty persists: Poverty dynamics in Asia and Africa, ed. Bob Baulch. Northhampton, MA: Edward Elgar Publishing, Inc.

Baulch, Bob, Hung T Pham, and Barry Reilly. (2012). "Decomposing the ethnic gap in Vietnam, 1993-2004," Oxford Development Studies, 40(1), 87-117. 
Bhattacharya. (2013). "Inflation Dynamics and Monetary Policy Transmission in Vietnam and Emerging Asia." IMF Working Paper.

Benjamin, Dwayne and Loren Brandt. (2004). "Agriculture and income distribution in rural Vietnam under economic reforms: A tale of two regions," in Economic growth, poverty and household welfare in Vietnam, Eds. Paul Glewwe, Nisha Agrawal, and David Dollar. Washington, D.C.: The World Bank, 133-86.

Benjamin, Dwayne, Loren Brandt, and John Giles. (2005). "The evolution of income inequality in rural China." Economic Development and Cultural Change. 53(4), 769-824.

Benjamin, Dwayne, Loren Brandt, John Giles and Sangui Wang. (2008). "Income inequality during China's economic transition." in China's Great Economic Transformation, Eds. Loren Brandt and Thomas Rawski. Cambridge, MA: Cambridge University Press, 729-755.

Benjamin, Dwayne, Loren Brandt, and Brian McCaig. (2009). "The evolution of income inequality in Vietnam, 1993-2006." Chapter 2 in Brian McCaig, Empirical Essays on Poverty, Inequality, and Social Welfare. PhD Dissertation, University of Toronto.

Cling, Jean-Pierre, Mohamed Ali Marouani, Mireille Razafindrakoto, Anne-Sophie Robilliard, and Francois Roubaud. (2009). "The distributive impact of Vietnam's accession to the WTO," International Economics, 118(2), 43-71.

Cowell, Frank A., Julie A. Litchfield and Magda Mercader-Prats. (1999). "Income inequality comparisons with dirty data: The UK and Spain during the 1980s." Distributional Analysis Research Programme Discussion Paper No. 45.

Coxhead, Ian, Linh Hoang Vu and Le Dong Tam. (2012). "Global market shocks and poverty in Vietnam: the case of rice." Agricultural Economics, 43(5), 575-592.

Diep, Phan and Ian Coxhead. (2010). "Inter-provincial migration and inequality during Vietnam's transition." Journal of Development Economics, 91(1), 100-112.

Edmonds, Eric and Nina Pavcnik. (2006). "Trade liberalization and the allocation of labor between households and markets in a poor country," Journal of International Economics, 69(2), 257-95. 
Fukase, Emiko. (2013). "Foreign job opportunities and internal migration in Vietnam," World Bank Policy Research Working Paper No. 6420.

General Statistics Office. (2008). Operational Handbook: Vietnam Household Living Standards Survey 2008, Ha Noi.

Gibson, John, Trinh Le, and Bonggeun Kim. (2014). "Prices, Engel Curves and time-space deflation: Impacts on poverty and inequality in Vietnam," mimeo.

Glewwe, Paul, Michele Gragnolati, and Hassan Zaman. (2002). "Who gained from Vietnam's boom in the 1990s?" Economic Development and Cultural Change, 50(4), 773-92.

Glewwe, Paul. (2004). "An overview of economic growth and household welfare in Vietnam in the 1990s," in Economic growth, poverty and household welfare in Vietnam, Eds. Paul Glewwe, Nisha Agrawal, and David Dollar. Washington, D.C.: The World Bank, 1-26.

Glewwe, Paul. (2007). "Measurement Error Bias in Estimates of Income and Income Growth among the Poor: Analytical Results and a Correction Formula." Economic Development and Cultural Change, 56(1), 163-189.

Glewwe, Paul. (2012). "How much of observed economic mobility is measurement error? IV methods to reduce measurement error bias, with an application to Vietnam." The World Bank Economic Review, 26(2), 236-264.

Jenkins, Stephen P. (1995). "Accounting for inequality trends: Decomposition analysis for the UK, 1971-86," Economica, 62(245), 29-63.

Khan, Azizur Rahman and Carl Riskin. (1998). "Income and inequality in China: Composition, distribution and growth of household income, 1988 to 1995," The China Quarterly, 154, 221-253. Knight, John. (2014). "Inequality in China: An overview," The World Bank Economic Review, $29(1), 1-19$.

Lerman, Robert I. and Shlomo Yitzhaki. (1985). "Income inequality effects by income source: A new approach and applications to the United States," The Review of Economics and Statistics, 67(1), 151-156. 
Li, Shi, Hiroshi Sato and Terry Sicular (Editors). (2013). Rising Inequality in China: Challenges to a Harmonious Society. New York: Cambridge University Press.

McCaig, Brian. (2011). "Exporting out of poverty: Provincial poverty in Vietnam and U.S. market access," Journal of International Economics, 85(1), 102-113.

McCaig, Brian and Nina Pavcnik. (2013). "Moving out of agriculture: Structural change in Vietnam," NBER Working Paper No. 19616.

McCaig, Brian and Nina Pavcnik. (2014). "Export markets and labor allocation in a poor country," NBER Working Paper No. 20455.

McCaig, Brian and Nina Pavcnik. (2015). "Informal employment in a growing and globalizing low-income country," American Economic Review, 105(5), 545-50.

Park, Albert, Xiaoqing Song, Junsen Zhang, and Yaohui Zhao. (2005). "Economic Returns to Schooling in Urban China, 1998-2001." Journal of Comparative Economics, 33(4), 730-752.

Phung Duc Tung, and Nguyen Phong. (n.d.) Vietnam Household Living Standards Survey (VHLSS), 2002 and 2004: Basic Information.

Shi, Li, and Terry Sicular. (2014). "The distribution of household income in China: Inequality, poverty and policies," The China Quarterly, 217, 1-41.

Shorrocks, Anthony F. (1982). "Inequality decomposition by factor components," Econometrica, 50(1), 193-211.

van de Walle, Dominique and Dileni Gunewardena. (2001). "Sources of ethnic inequality in Viet Nam," Journal of Development Economics, 65(1), 177-207.

van de Walle, Dominique and Dorothyjean Cratty. (2004). "Is the emerging non-farm market economy the route out of poverty in Vietnam?" Economics of Transition, 12(2), 237-274.

VASS (Vietnam Academy of Social Sciences). (2006). Vietnam poverty update report 2006: Poverty and poverty reduction in Vietnam 1993-2004. Hanoi: The National Political Publisher. VASS (Vietnamese Academy of Social Sciences). (2011). Poverty Reduction in Viet Nam: Achievements and Challenges. Hanoi: The World Publisher. 
World Bank. (2013). Vietnam Poverty Assessment: well begun, not yet done - Vietnam's remarkable progress on poverty reduction and the emerging challenges. Report, Washington, D.C.: World Bank.

Yu Xie and Xiang Zhou.(2014). "Income Inequality in today's China," Proceedings of the National Academy of Sciences. 111(19), 6928-6933. 
Table 1: Income and Inequality, All Vietnam

\begin{tabular}{|c|c|c|c|c|c|c|c|c|}
\hline & 2002 & 2004 & 2006 & 2008 & 2010 & 2012 & 2014 & Delta \\
\hline \multicolumn{9}{|l|}{ Average Per Capita: } \\
\hline Household Income & 11,318 & 14,166 & 16,074 & 18,257 & 21,790 & 23,992 & 25,843 & 6.9 \\
\hline Household Consumption & 9,188 & 11,648 & 11,913 & 13,682 & 22,521 & 23,098 & 23,923 & 8.0 \\
\hline \multicolumn{9}{|l|}{ Inequality: } \\
\hline Gini - Income & $\begin{array}{c}0.375 \\
(0.003)\end{array}$ & $\begin{array}{c}0.370 \\
(0.004)\end{array}$ & $\begin{array}{c}0.374 \\
(0.004)\end{array}$ & $\begin{array}{c}0.389 \\
(0.005)\end{array}$ & $\begin{array}{c}0.396 \\
(0.005)\end{array}$ & $\begin{array}{c}0.375 \\
(0.004)\end{array}$ & $\begin{array}{c}0.360 \\
(0.003)\end{array}$ & -0.015 \\
\hline Gini - Consumption & $\begin{array}{c}0.342 \\
(0.002)\end{array}$ & $\begin{array}{c}0.350 \\
(0.004)\end{array}$ & $\begin{array}{c}0.335 \\
(0.003)\end{array}$ & $\begin{array}{c}0.333 \\
(0.004)\end{array}$ & $\begin{array}{c}0.380 \\
(0.005)\end{array}$ & $\begin{array}{c}0.350 \\
(0.004)\end{array}$ & $\begin{array}{c}0.336 \\
(0.004)\end{array}$ & -0.005 \\
\hline Theil - Income & $\begin{array}{c}0.255 \\
(0.005)\end{array}$ & $\begin{array}{c}0.249 \\
(0.008)\end{array}$ & $\begin{array}{c}0.255 \\
(0.008)\end{array}$ & $\begin{array}{c}0.278 \\
(0.011)\end{array}$ & $\begin{array}{c}0.281 \\
(0.009)\end{array}$ & $\begin{array}{c}0.252 \\
(0.007)\end{array}$ & $\begin{array}{c}0.225 \\
(0.005)\end{array}$ & -0.030 \\
\hline Theil - Consumption & $\begin{array}{c}0.212 \\
(0.004)\end{array}$ & $\begin{array}{c}0.218 \\
(0.005)\end{array}$ & $\begin{array}{c}0.196 \\
(0.005)\end{array}$ & $\begin{array}{c}0.193 \\
(0.005)\end{array}$ & $\begin{array}{c}0.269 \\
(0.011)\end{array}$ & $\begin{array}{c}0.217 \\
(0.007)\end{array}$ & $\begin{array}{c}0.200 \\
(0.006)\end{array}$ & -0.012 \\
\hline Sample Size & 29,026 & 9,041 & 9,020 & 9,011 & 9,218 & 9,225 & 9,223 & \\
\hline $\begin{array}{l}\text { Notes: (1) This table } r \\
\text { Vietnam; (2) Values in t } \\
\text { is the average annual gro } \\
\text { for levels of income), ar } \\
\text { measures. }\end{array}$ & $\begin{array}{l}\text { orts me } \\
\text { usands }\end{array}$ & ures of & nean per & capita il & me anc & inequali & by yea & $\begin{array}{l}\text { for all o } \\
\text { "Delta" } \\
\text { arcentage } \\
\text { nequality }\end{array}$ \\
\hline
\end{tabular}


Table 2: Urban/Rural and Spatial Dimensions of Inequality

\begin{tabular}{|c|c|c|c|c|c|c|c|c|}
\hline & 2002 & 2004 & 2006 & 2008 & 2010 & 2012 & 2014 & $\overline{\text { Delta }}$ \\
\hline Percentage Urban & 22.7 & 23.6 & 23.5 & 27.6 & 29.7 & 29.6 & 31.4 & 8.8 \\
\hline \multicolumn{9}{|l|}{ Per Capita Income } \\
\hline Rural & 9,568 & 12,068 & 13,858 & 15,333 & 17,952 & 20,909 & 22,527 & 7.1 \\
\hline Urban & 17,291 & 20,953 & 23,295 & 25,926 & 30,891 & 31,311 & 33,079 & 5.4 \\
\hline Ratio (Urban/Rural) & 1.81 & 1.74 & 1.68 & 1.69 & 1.72 & 1.50 & 1.47 & -0.34 \\
\hline \multicolumn{9}{|l|}{ Inequality } \\
\hline \multicolumn{9}{|l|}{ Gini } \\
\hline Rural & $\begin{array}{c}0.341 \\
(0.002)\end{array}$ & $\begin{array}{c}0.344 \\
(0.004)\end{array}$ & $\begin{array}{c}0.353 \\
(0.005)\end{array}$ & $\begin{array}{c}0.364 \\
(0.004)\end{array}$ & $\begin{array}{c}0.371 \\
(0.005)\end{array}$ & $\begin{array}{c}0.375 \\
(0.004)\end{array}$ & $\begin{array}{c}0.365 \\
(0.005)\end{array}$ & 0.025 \\
\hline Urban & $\begin{array}{c}0.365 \\
(0.004)\end{array}$ & $\begin{array}{c}0.351 \\
(0.008)\end{array}$ & $\begin{array}{c}0.350 \\
(0.009)\end{array}$ & $\begin{array}{c}0.374 \\
(0.011)\end{array}$ & $\begin{array}{c}0.375 \\
(0.009)\end{array}$ & $\begin{array}{c}0.337 \\
(0.008)\end{array}$ & $\begin{array}{c}0.313 \\
(0.006)\end{array}$ & -0.052 \\
\hline \multicolumn{9}{|l|}{ Theil } \\
\hline Rural & $\begin{array}{c}0.209 \\
(0.004)\end{array}$ & $\begin{array}{c}0.211 \\
(0.007)\end{array}$ & $\begin{array}{c}0.224 \\
(0.007)\end{array}$ & $\begin{array}{c}0.238 \\
(0.007)\end{array}$ & $\begin{array}{c}0.242 \\
(0.009)\end{array}$ & $\begin{array}{c}0.248 \\
(0.007)\end{array}$ & $\begin{array}{c}0.233 \\
(0.008)\end{array}$ & 0.024 \\
\hline Urban & $\begin{array}{c}0.236 \\
(0.007)\end{array}$ & $\begin{array}{c}0.227 \\
(0.014)\end{array}$ & $\begin{array}{c}0.230 \\
(0.016)\end{array}$ & $\begin{array}{c}0.260 \\
(0.019)\end{array}$ & $\begin{array}{c}0.252 \\
(0.016)\end{array}$ & $\begin{array}{c}0.208 \\
(0.014)\end{array}$ & $\begin{array}{c}0.170 \\
(0.008)\end{array}$ & -0.066 \\
\hline \multicolumn{9}{|c|}{ Decompositions ("Between" inequality as percentage of All-Vietnam Theil): } \\
\hline Urban/Rural & 14.4 & 13.0 & 11.1 & 11.3 & 12.3 & 7.4 & 7.6 & -6.8 \\
\hline Provinces & 20.7 & 17.3 & 14.9 & 15.2 & 17.9 & 12.6 & 10.3 & -10.4 \\
\hline Provinces $\times$ Urban/Rural & 27.9 & 25.0 & 22.5 & 22.6 & 24.7 & 18.5 & 16.9 & -11.0 \\
\hline \multicolumn{9}{|c|}{$\begin{array}{l}\text { Notes: (1) This table reports measures of mean per capita income and inequality by year separately } \\
\text { for Urban and Rural Vietnam; (2) Values in thousands of constant } 2012 \text { VND; (3) Standard errors in } \\
\text { parentheses; (4) "Delta" is the average annual rate of growth of per capita incomes between } 2002 \text { and } \\
2014 \text { (in percentage terms for levels of income), and the change in levels between } 2002 \text { and } 2014 \text { for the } \\
\text { other variables; (5) The decompositions represent the percentage of the overall income Theil for Vietnam } \\
\text { (from Table 1) that can be attributed to inequality between (i) urban and rural, (ii) provinces, and (iii) } \\
\text { urban/rural interacted with province. }\end{array}$} \\
\hline
\end{tabular}


Table 3: Minority Dimensions of Rural Inequality

\begin{tabular}{|c|c|c|c|c|c|c|c|c|}
\hline & 2002 & 2004 & 2006 & 2008 & 2010 & 2012 & 2014 & Delta \\
\hline Percentage Minority & 14.6 & 15.1 & 16.0 & 16.3 & 18.0 & 18.4 & 18.3 & 3.7 \\
\hline \multicolumn{9}{|l|}{ Per Capita Income } \\
\hline Kinh & 10,148 & 12,900 & 14,912 & 16,520 & 19,642 & 23,093 & 24,840 & 7.5 \\
\hline Minority & 6,179 & 7,394 & 8,310 & 9,231 & 10,243 & 11,206 & 12,194 & 5.7 \\
\hline Ratio & 1.64 & 1.74 & 1.79 & 1.79 & 1.92 & 2.06 & 2.04 & 0.40 \\
\hline \multicolumn{9}{|c|}{ Minorities in the bottom decile: } \\
\hline As \% of Minorities: & 25.2 & 28.8 & 29.6 & 27.8 & 30.3 & 34.1 & 35.6 & 10.3 \\
\hline As $\%$ of Decile & 36.9 & 43.5 & 47.2 & 45.3 & 54.5 & 62.6 & 65.0 & 28.1 \\
\hline \multicolumn{9}{|l|}{ Inequality } \\
\hline Kinh & $\begin{array}{c}0.334 \\
(0.002)\end{array}$ & $\begin{array}{c}0.332 \\
(0.005)\end{array}$ & $\begin{array}{c}0.342 \\
(0.005)\end{array}$ & $\begin{array}{c}0.350 \\
(0.004)\end{array}$ & $\begin{array}{c}0.352 \\
(0.005)\end{array}$ & $\begin{array}{c}0.349 \\
(0.006)\end{array}$ & $\begin{array}{c}0.333 \\
(0.005)\end{array}$ & 0.000 \\
\hline Minority & $\begin{array}{c}0.294 \\
(0.006)\end{array}$ & $\begin{array}{c}0.309 \\
(0.010)\end{array}$ & $\begin{array}{c}0.300 \\
(0.012)\end{array}$ & $\begin{array}{c}0.331 \\
(0.011)\end{array}$ & $\begin{array}{c}0.339 \\
(0.008)\end{array}$ & $\begin{array}{c}0.361 \\
(0.010)\end{array}$ & $\begin{array}{c}0.388 \\
(0.014)\end{array}$ & 0.095 \\
\hline \multicolumn{9}{|l|}{ Theil } \\
\hline Kinh & $\begin{array}{c}0.201 \\
(0.004)\end{array}$ & $\begin{array}{c}0.198 \\
(0.008)\end{array}$ & $\begin{array}{c}0.211 \\
(0.007)\end{array}$ & $\begin{array}{c}0.222 \\
(0.007)\end{array}$ & $\begin{array}{c}0.220 \\
(0.009)\end{array}$ & $\begin{array}{c}0.218 \\
(0.009)\end{array}$ & $\begin{array}{c}0.197 \\
(0.008)\end{array}$ & -0.004 \\
\hline Minority & $\begin{array}{c}0.155 \\
(0.008)\end{array}$ & $\begin{array}{c}0.176 \\
(0.015)\end{array}$ & $\begin{array}{c}0.173 \\
(0.022)\end{array}$ & $\begin{array}{c}0.208 \\
(0.022)\end{array}$ & $\begin{array}{c}0.209 \\
(0.013)\end{array}$ & $\begin{array}{c}0.241 \\
(0.017)\end{array}$ & $\begin{array}{c}0.290 \\
(0.034)\end{array}$ & 0.135 \\
\hline \multicolumn{9}{|c|}{ Decompositions ("Between" group inequality as percentage of All-Vietnam Theil): } \\
\hline Minority/Kinh & 5.8 & 7.2 & 7.7 & 7.3 & 9.6 & 11.3 & 11.7 & 5.9 \\
\hline $\begin{array}{l}\text { Notes: (1) This tabl } \\
\text { Vietnam, partitioned } \\
2012 \text { VND; (3) Stand } \\
\text { capita incomes betwee } \\
\text { between } 2002 \text { and } 20 \\
\text { minorities in the bott } \\
\text { (6) The decompositio } \\
\text { Table 2) that can be }\end{array}$ & $\begin{array}{l}\text { reports } \\
\text { by ethnic } \\
\text { ard errors } \\
2002 \text { an } \\
4 \text { for the } \\
\text { om decile } \\
\text { n represel }\end{array}$ & $\begin{array}{l}\text { measures } \\
\text { minority } \\
\text { in paren } \\
\text { d } 2014 \text { (in } \\
\text { other var } \\
\text { as well a } \\
\text { its the pe }\end{array}$ & $\begin{array}{l}\text { of mean } \\
\text { tatus (M } \\
\text { heses; } \\
\text { percenta } \\
\text { ables; ( }\end{array}$ & $\begin{array}{l}\text { per capi } \\
\text { nority or } \\
\text { "Delta" } \\
\text { e terms } \\
\text { For the }\end{array}$ & $\begin{array}{l}\text { ancome } \\
\text { Kinh); ( } \\
\text { s the av } \\
\text { r levels } \\
\text { pottom } \\
\text { the bott }\end{array}$ & $\begin{array}{l}\text { and inec } \\
\text { Values } \\
\text { age ann } \\
\text { income) } \\
\text { cile, we } \\
\text { m decile } \\
\text { e Theil } \\
\text { inh. }\end{array}$ & $\begin{array}{l}\text { iality by } \\
\text { n thousa } \\
\text { al rate o } \\
\text { and the } \\
\text { eport th } \\
\text { comprise } \\
\text { or Rural }\end{array}$ & $\begin{array}{l}\text { r for rural } \\
\text { of constant } \\
\text { wth of per } \\
\text { ge in levels } \\
\text { rcentage of } \\
\text { minorities; } \\
\text { nam (from }\end{array}$ \\
\hline
\end{tabular}


Table 4: The structure of household income, 2002 and 2014

\begin{tabular}{|c|c|c|c|c|c|}
\hline & \multicolumn{3}{|c|}{ Level } & \multicolumn{2}{|c|}{ Share } \\
\hline & 2002 & 2014 & Growth & 2002 & 2014 \\
\hline Crop income & 2,289 & 3,421 & 3.3 & 20.2 & 13.2 \\
\hline Sideline income & 1,173 & 1,805 & 3.6 & 10.4 & 7.0 \\
\hline Family business & 2,603 & 5,751 & 6.6 & 23.0 & 22.3 \\
\hline Wages & 3,456 & 10,886 & 9.6 & 30.5 & 42.1 \\
\hline Remittances & 1,070 & 1,733 & 4.0 & 9.5 & 6.7 \\
\hline Other income & 727 & 2,247 & 9.4 & 6.4 & 8.7 \\
\hline \multirow[t]{3}{*}{ Total } & 11,318 & 25,843 & 6.9 & & \\
\hline & \multicolumn{3}{|c|}{ Conditional on Positive } & \multicolumn{2}{|c|}{ Participation } \\
\hline & 2002 & 2014 & Growth & 2002 & 2014 \\
\hline Crop income & 3,205 & 5,650 & 4.7 & 71.5 & 60.9 \\
\hline Sideline income & 1,730 & 3,694 & 6.3 & 68.2 & 49.3 \\
\hline Family business & 6,348 & 16,305 & 7.9 & 41.0 & 35.3 \\
\hline Wages & 5,775 & 15,462 & 8.2 & 59.8 & 70.4 \\
\hline Remittances & 1,364 & 2,004 & 3.2 & 78.5 & 86.5 \\
\hline Other income & 1,878 & 4,981 & 8.1 & 38.7 & 45.1 \\
\hline \multicolumn{6}{|c|}{$\begin{array}{l}\text { Notes: (1) This table reports mean per capita household income by } \\
\text { source, in constant } 2012 \text { VND; (2) In the top panel, we show the un- } \\
\text { conditional means, the implied annual percentage-rate growth of rate } \\
\text { between } 2002 \text { and } 2014 \text {, and the percentage share of total income by } \\
\text { source; (3) In the bottom panel, we report average income by source } \\
\text { conditional on positive, the implied annual percentage-rate growth of } \\
\text { rate between } 2002 \text { and } 2014 \text {, and the percentage of households with pos- } \\
\text { itive earnings for that source (i.e., the participation rate). }\end{array}$} \\
\hline
\end{tabular}

Table 5: Composition of Income by Quartile Group

\begin{tabular}{|c|c|c|c|c|c|}
\hline \multirow[t]{2}{*}{2002} & \multicolumn{4}{|c|}{ Quartile } & \multirow[b]{2}{*}{ Q1-Q4 } \\
\hline & 1 & 2 & 3 & 4 & \\
\hline Crop income & 39.7 & 29.7 & 23.6 & 9.7 & 30.0 \\
\hline Sideline income & 15.2 & 14.1 & 12.1 & 6.7 & 8.5 \\
\hline Family business & 9.9 & 17.0 & 22.8 & 28.8 & -19.0 \\
\hline Wages & 25.8 & 27.8 & 27.8 & 34.3 & -8.5 \\
\hline Remittances & 5.3 & 6.3 & 7.6 & 12.7 & -7.4 \\
\hline Other income & 4.1 & 5.1 & 6.1 & 7.8 & -3.7 \\
\hline \multirow[t]{2}{*}{2014} & \multicolumn{4}{|c|}{ Quartile } & \\
\hline & 1 & 2 & 3 & 4 & Q1-Q4 \\
\hline Crop income & 24.8 & 17.4 & 13.8 & 7.4 & 17.4 \\
\hline Sideline income & 10.9 & 9.8 & 8.1 & 3.7 & 7.1 \\
\hline Family business & 9.8 & 18.5 & 22.4 & 27.7 & -17.9 \\
\hline Wages & 43.4 & 42.3 & 41.9 & 41.8 & 1.6 \\
\hline Remittances & 5.9 & 6.5 & 6.8 & 7.0 & -1.1 \\
\hline Other income & 5.3 & 5.4 & 6.9 & 12.5 & -7.1 \\
\hline
\end{tabular}

Notes: (1) This table reports the average share of income by source by quartile group; (2) Quartiles are calculated in the basis of household per capita non-food consumption; (3) The final column provides the difference in percentages of income from a given source between the lowest (Q1) and highest (Q4) quartile groups. 
Table 6: Decomposing Income Inequality by Source of Income, 2002 and 2014

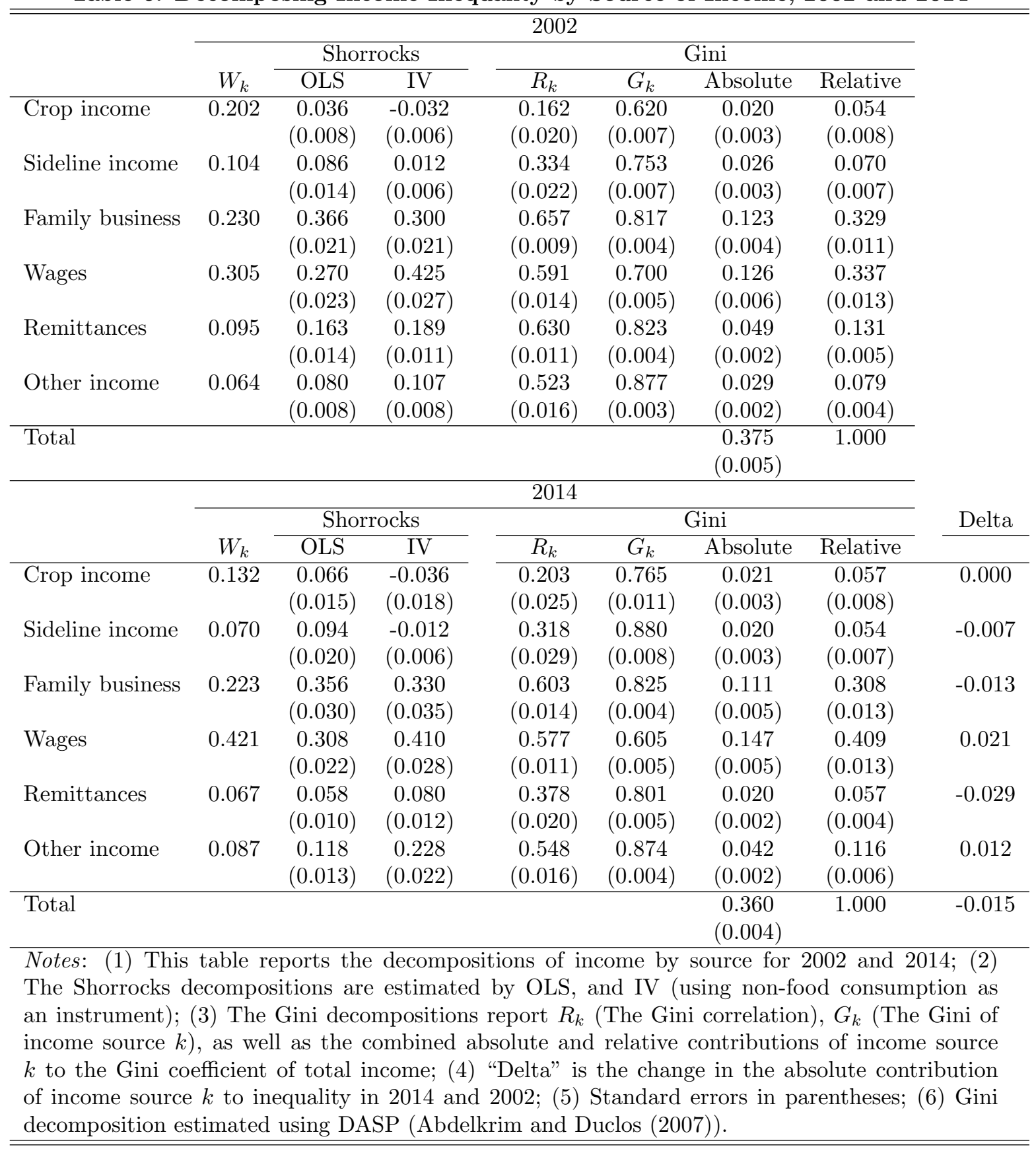


Table 7: Selected Inequality (Gini) Estimates for China, 1991 and 2001

\begin{tabular}{|c|c|c|c|c|c|c|c|}
\hline \multirow[b]{2}{*}{ Source } & \multirow[b]{2}{*}{ Data } & \multicolumn{3}{|c|}{1991} & \multicolumn{3}{|c|}{2001} \\
\hline & & Combined & Urban & Rural & Combined & Urban & Rural \\
\hline Ravallion \& Chen (2007) & NBS & 0.37 & 0.23 & 0.31 & 0.45 & 0.32 & 0.36 \\
\hline Benjamin et. al. (2008) & NBS & & 0.27 & & & 0.35 & \\
\hline Benjamin et. al. (2008) & CHNS & 0.37 & 0.29 & 0.39 & 0.44 & 0.38 & 0.46 \\
\hline Benjamin et. al. (2008) & CHNS, Coastal & 0.35 & 0.26 & 0.38 & 0.39 & 0.37 & 0.39 \\
\hline Benjamin et. al. (2008) & CHNS, Interior & 0.39 & 0.31 & 0.40 & 0.48 & 0.39 & 0.49 \\
\hline $\begin{array}{l}\text { Khan \& Riskin (1998); Li } \\
\text { \& Sicular (2014) }\end{array}$ & CHIP & 0.38 & 0.23 & 0.34 & 0.46 & & \\
\hline Benjamin et. al. (2005) & RCRE & & & 0.27 & & & 0.33 \\
\hline $\begin{array}{l}\text { Notes: (1) This table rep } \\
\text { The full sources are listed } \\
\text { refers to the annual househ } \\
\text { and Nutrition Survey; (iii) } \\
\text { household survey of the Re } \\
\text { CHIP are for 1988; the est }\end{array}$ & $\begin{array}{l}\text { ts selected Gini } \\
\text { a the Bibliograpl } \\
\text { ld survey of the I } \\
\text { CHIP is the Chi } \\
\text { earch Centre for } \\
\text { nates by Li and }\end{array}$ & $\begin{array}{l}\text { Househo } \\
\text { aral Econo } \\
\text { cular are }\end{array}$ & $\begin{array}{l};(4) \mathrm{T} \\
2002 .\end{array}$ & $\begin{array}{l}\text { istics; } \\
\text { rojec } \\
\text { estin }\end{array}$ & $\begin{array}{l}\text { HNS is th } \\
\text { (iv) RCI } \\
\text { of Khan ar }\end{array}$ & $\begin{array}{l}\text { China } \\
\text { ce: (i) } \\
\text { hina } \mathrm{H} \\
\text { is the } \\
\text { Riskin }\end{array}$ & $\begin{array}{l}(2) \\
\text { BS } \\
\text { lth } \\
\text { iral } \\
\text { ing }\end{array}$ \\
\hline
\end{tabular}

Figure 1: Income Levels and Income Growth by Percentile

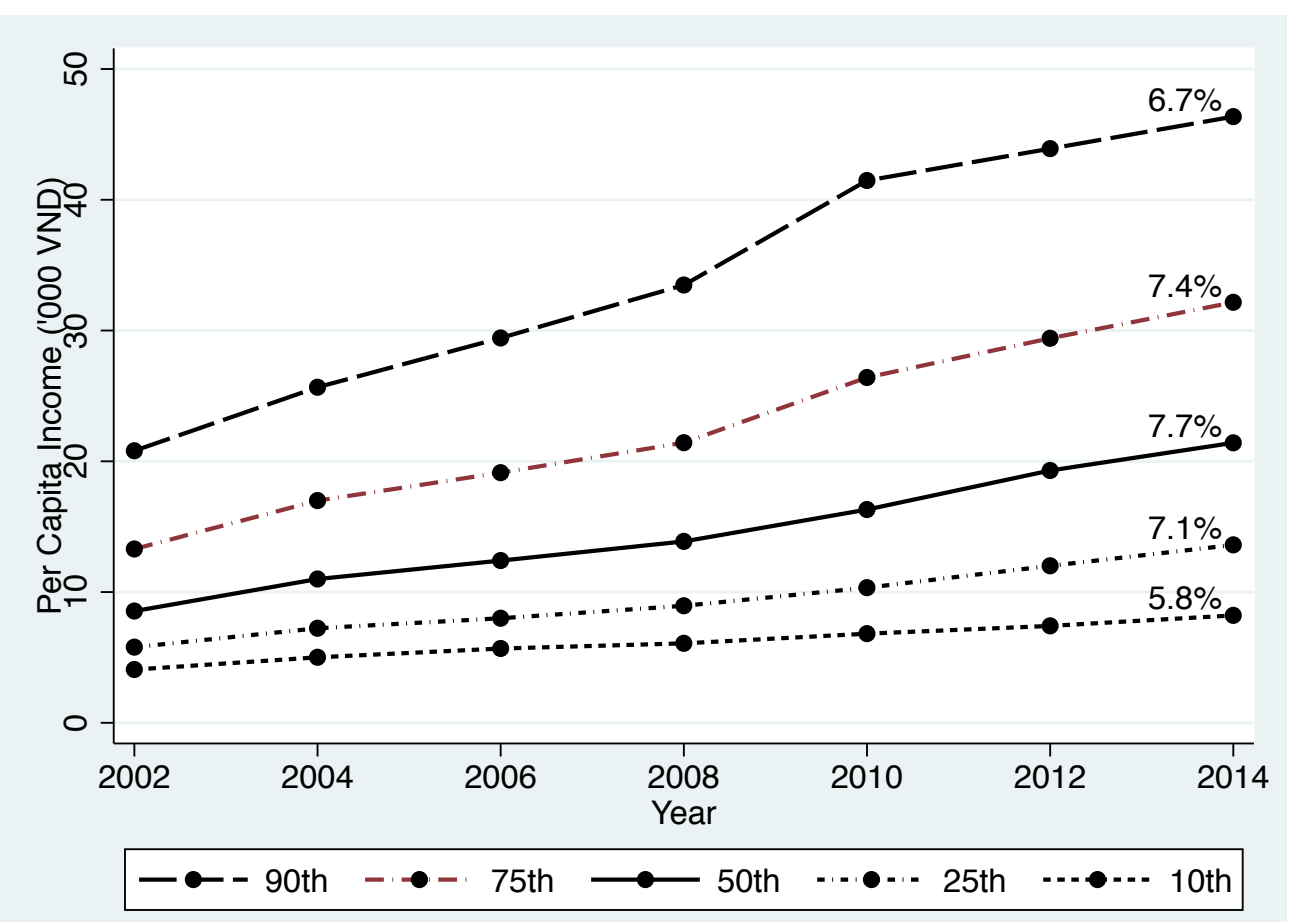

Notes: This figure reports average household per capita income by percentile. Beside each line, we report the average growth rate between 2002 and 2014 for that percentile. 
Figure 2: Lorenz Curves of Income per Capita, 2002 and 2014

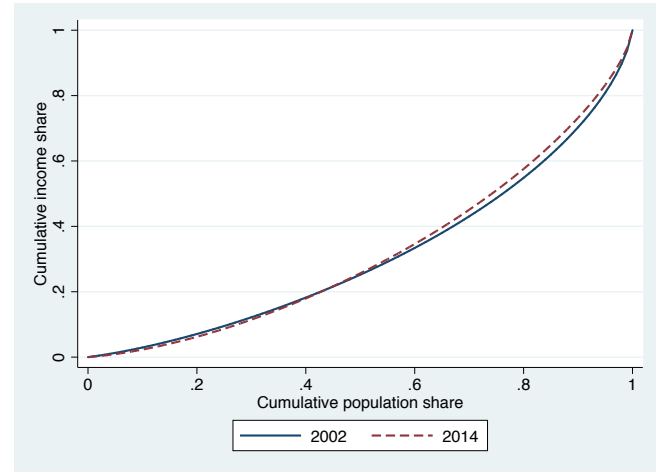

(a) Lorenz curves

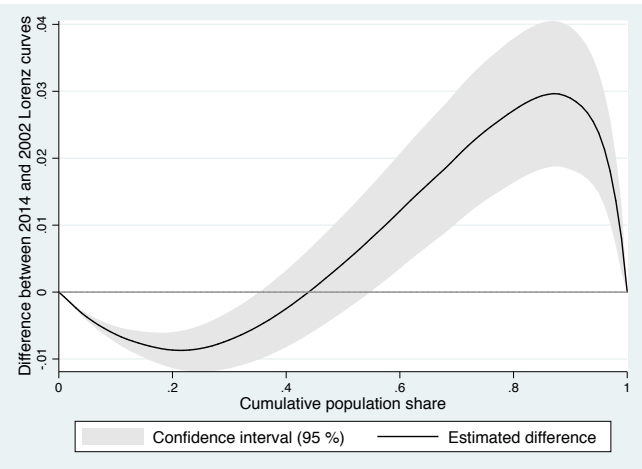

(b) Difference in Lorenz: 2014 - 2002

Notes: These figures show the Lorenz curves for household per capita income in 2002 and 2014. Panel (a) shows the Lorenz curves themselves, while panel (b) shows the 95 confidence intervals for the differences between the 2014 and 2002 Lorenz curves. Figures created using DASP (Abdelkrim and Duclos (2007)). 
APPENDICES 


\section{Outline}

These appendices provide supporting tables and figures for the main text. In Appendix A, we provide additional results (i.e., extra detail) to those tables in the text, while in Appendix B, we compare mean incomes and growth from the VHLSS surveys to analogs from the national accounts. More specifically:

- Details on the construction of comparable income estimates;

- Table A1: Sample sizes, trimmed and untrimmed samples;

- Table A2: Core results for untrimmed sample;

- Table A3: Urban/Rural dimensions of inequality using consumption (instead of income);

- Table A4A: The structure of rural household income;

- Table A4B: The structure of urban household income;

- Table A5A: Composition of income by quartile (Rural);

- Table A5B: Composition of income by quartile (Urban);

- Table A6A: Decomposing rural income inequality by source of income;

- Table A6B: Decomposing urban income inequality by source of income;

- Figure A1A: Rural Incomes and Growth by Percentile;

- Figure A1B: Urban Incomes and Growth by Percentile;

- Figure A2A: Lorenz Curves of Rural Income per Capita, 2002 and 2014;

- Figure A2B: Lorenz Curves of Urban Income per Capita, 2002 and 2014;

- Table B1: Comparing VHLSS to Aggregate Data.

\section{Appendix A Additional results}

\section{A.1 Details on the construction of comparable income estimates}

Here we provide further detail on how we constructed comparable estimates of household income across surveys. We begin by providing greater detail on the components of each income source before discussing regional deflators. 
Household income is composed of:

1. Crop income: This source includes crop-based farm income, whether from annuals (e.g., rice, other starchy crops, vegetables, industrial crops, etc.) or perennials (industrial crops, fruit, nuts, agro-forestry trees), and crop by-products. Income is revenue minus expenses. ${ }^{1}$

2. Agricultural sideline income: This includes livestock and other animal products (e.g., milk, honey), agricultural services (e.g., pest control), forestry services, hunting, trapping, domesticating wild animals, and aquaculture. Income is revenue minus expenses.

3. Non-farm business income: This includes all manufacturing (e.g., processing of agricultural products), service (e.g., retail), and mining activities undertaken by households. Income is revenue minus expenses. ${ }^{2}$

4. Wage earnings: This includes cash and in kind salary or wage payments plus additional payments such as holiday contributions, social insurance payments, etc. for all jobs worked by household members during the past 12 months.

5. Gifts and remittances: Gifts and remittance payments (including in-kind) comprise both domestic and overseas sources. This includes wage earnings remitted to the household from family members working elsewhere in Vietnam. It is not possible, however, to identify this income specifically as "wage" versus some other source of earnings, nor is it possible to attribute it to a specific family member.

6. "Other" sources of income: This includes government transfers (pension, sickness, one-time job allowance, and social insurance allowance), income from insurance, earned interest, and rental income from workshops, machinery, land, and housing.

\footnotetext{
${ }^{1}$ We estimate the revenue generated from each crop by the household as the quantity harvested multiplied by the unit value ("price") for sold output. For households that did not sell any output (i.e., those who consumed all of their output), we use the median unit value at the most local level available (commune, province, region, or national). We use the same procedure for agricultural sidelines.

${ }^{2}$ Revenue is the reported value of output (including by-products) sold, exchange, or consumed by the household during the past 12 months. Annual expenses are the reported value of all expenses (e.g., materials, tools, labour, rent, taxes and fees, etc.) except depreciation. A small percentage of businesses in each survey do not have reported expenditures. Most of these businesses are very small in terms of revenue and thus it is plausible that the true value of unreported expenditures is zero. However, a small number of these businesses are very large in terms of revenue (e.g., above the 90th percentile of business revenue) and thus we impute business expenditures for all businesses with missing expenditure information.
} 
Note that because of survey limitations, we are not able to credibly and consistently calculate imputed rent, or the imputed flow of services of durables.

World Bank (2013) and Gibson et al. (2014) describe how the regional deflators included with the 2002 through 2008 VHLSSs are not based on price data collected for the purpose of spatial comparisons, but instead on price data collected for facilitating comparisons over time. Therefore, these price data should not be used for the construction of regional deflators. Instead, we use the regional deflators provided by Gibson et al. (2014) based on price data collected in 2010 for the purpose of spatial comparisons. We use these deflators for all surveys as differences in spatial costs do not change quickly over short periods (Gibson et al. (2014)). Although the level of inequality is sensitive to the choice of regional deflators (i.e., deflating high incomes in high cost cities), the trends are not. Results with alternative strategies for spatial deflation are available upon request.

\section{A.2 Sample sizes and main results using untrimmed sample}

As we explain in the text, our trimming procedure is designed to reduce the influence of potentially miscoded or mis-measured outliers, either zero or negative incomes, or extremely high incomes. In Table A1, we report the sample sizes of the full untrimmed, as well as the trimmed samples. The 2002 survey is clearly the largest, with almost 30,000 observations. The sample size in subsequent years is closer to 9,000 . The trimmed sample contains over 98 percent of observations for each year.

We report mean per capita income and consumption and inequality estimates for the untrimmed sample in Table A2. These can be compared directly to Tables 1 and 2 in the main text. The bottom line is that results using the untrimmed sample of households are consistent with our main results. First, the mean income and consumption levels are all comparable with the trimmed sample results (Table 1), differing by at most a few percentage points. Second, growth in mean per capita income and consumption is largely unaffected by trimming as the annual growth rates differ by only 0.2 percentage points.

In Table A2 we see that the level of inequality is higher using the untrimmed sample, as one would expect. For example, estimates for the Gini coefficient of per capita income are about 0.02 points higher for all of Vietnam, with a range of 0.01 to 0.03 across survey years. We see similar differences between the trimmed and untrimmed samples in urban and rural subsamples. 
The differences between samples are slightly smaller for per capita consumption, as we would expect given that trimming is conducted on the basis of measured income (not consumption). Most importantly for our purposes, the changes in inequality over time are consistent between the untrimmed and trimmed samples. Both samples lead to an estimated increase in rural inequality, a decrease in urban inequality, and a slight decrease in overall inequality. Our main results, which are based on the trimmed sample, are therefore robust to the inclusion of outliers. We may, however, be understating the absolute level of inequality depending on what proportion of outliers is due to measurement error, as opposed to genuinely extreme levels of household income.

\section{A.3 The distribution of growth in rural and urban areas}

The growth in mean income within rural areas was experienced throughout the income distribution (see Figure A1A). Even the bottom decile experienced 5.2 percent average growth, and this is likely to be reflected in significant reductions in poverty. However, growth rates are generally higher as one moves up the percentiles. The top fifty percent of the income distribution had rates of growth over 7 percent. To the extent that inequality may rise in rural areas, it is not being driven by a separation of the very richest from the rest of the pack, as much as a lagging behind of the poorest households in the 25 th percentile and lower.

In Figure A1B, we show comparable results for urban households. Here, the picture is notably different. Incomes grow more quickly in the bottom of the distribution. Clearly, urban poverty will decline when the bottom decile of households experiences growth of over 6 percent per annum. Between 2002 and 2014, urban inequality fell due to the faster growth of incomes in the bottom of the distribution (see Table 2). For the upper end of the distribution, 2012 and 2014 represent something of a break in trend, as incomes at higher percentiles either grew more slowly, or declined. This leads to a significant narrowing of the absolute, and proportional, income differences between the top (90th and 75th) percentiles, and the remainder of the distribution between 2010 and 2014. To explore this more closely, we examined incomes by source and percentile over the same period. Almost all of the downward tilt of the top percentiles' incomes comes from a reduction or decline in the growth of wage and remittance income. High wage earners were evidently hit hard by macroeconomic shocks to the labour market after 2010, which almost certainly affected the trajectory of inequality that had been established earlier in the decade. The income results are 
also reflected in the consumption numbers (compare Table 2 and Table A3), and we believe that the observed compression after 2010 is real as opposed to driven by measurement error or a change in survey methodology. Whether it remains a permanent feature of the income distribution going forward is a separate question, and highlights the fact that there is genuine time series variation in inequality.

The primary lesson from these figures, however, is that growth rates of per capita income were relatively strong across the distribution, with the notable exception of the poorest households in rural areas, many of which are ethnic minorities (see Table 3).

In Figure A2A we plot Lorenz curves for the income distributions of the rural sample for the endpoint years, 2002 and 2014. Does a clear picture of changes of inequality emerge? For rural households, the Lorenz curve for 2014 appears strictly below that for 2002, except for beyond about the 85 th percentile. We plot the difference between these two Lorenz curves, and the $95 \%$ confidence interval of the difference. The difference is statistically significant from zero over most of the domain of the Lorenz curve. The two curves are indistinguishable after the 85th percentile. This suggests that one cannot reject the hypothesis that the 2002 distribution Lorenz dominates the 2014 distribution.

As expected, the picture is reversed for urban households (see Figure A2B). The more recent 2014 Lorenz curve lies above that for 2002, and the difference is also statistically significantly different from zero for most of the domain, essentially between the 10th and 95th percentiles. Together, these results suggest that while urban inequality has fallen, rural inequality has risen over the period.

\section{A.4 Consumption inequality}

Table A3 replicates some of our results from Table 2 using consumption: Does the overall picture concerning growth and inequality in the rural and urban samples change when we use consumption instead of income as a measure of household resources? The consumption estimates confirm faster growth in rural areas compared to urban areas, leading to a reduction in the urban-rural gap of 0.40 (versus 0.34 for income, as reported in Table 2). Similarly, consumption inequality increases in rural areas and decreases in urban areas, consistent with the income inequality estimates in Table 2. 


\section{A.5 The structure of rural and urban income}

Tables A4A and A4B provide information on the structure of income for rural and urban Vietnam, respectively, in 2002 and 2014. In the top panel of each table we report income from each source for each year, and the implied annual average growth rates between 2002 and 2014, as well as the share of total income from each source. In the bottom panel, we report mean income conditional on being active and the rate of household participation.

In 2002, income from farming, i.e., cropping and agricultural sidelines, was enjoyed by most rural households and was the major source of rural income, at over 40 percent of total household income. More than half of all households had family members earning wage income, which was the source of 24.0 percent of all income. Wages and remittances combined were about a third of household income. Family businesses, on the other hand, contributed 18.9 percent to total income, with 36.7 percent of all households running at least one family business.

Changes in the structure of the rural economy between 2002 and 2014 are reflected in the growth rates by income source. Especially noteworthy are new labor market opportunities in industry and services which contributed to rapid growth of wage earnings of 10.7 percent per annum. Income from family businesses also grew slightly faster than average incomes, increasing at rate of 7.3 percent per annum. As expected, income growth in agriculture lagged, but even with the shock to incomes after 2008 caused by falling global farm prices, growth in crop incomes still averaged a respectable 3.8 percent over the full period, and sidelines mustered 4.8 percent growth. Growth in incomes in the farming sector is also more rapid if we condition on participation, 5.5 percent per annum versus 4.2 percent. Over this period, participation in agriculture declined by about one percentage point per year, as households moved to other activities.

Cumulatively, these shifts contributed to marked changes in the composition of rural income. By 2014, wages represented 36.9 percent of household income, an increase of 12.9 percentage points, and wages plus remittances more than 40 percent. $^{3}$ This increase came at the expense of farming, and in 2014, cropping and agricultural sidelines contributed only 30.1 percent to average per household incomes compared to 43.1 percent in 2002. Participation in family run businesses

\footnotetext{
${ }^{3}$ In a separate analysis we used the individual-level data to explore patterns of wage-labour participation by age, education, and gender. The bottom line is that increased wage labour participation is widespread across all subgroups in rural areas. The only slight exception is slower participation growth for the declining share of individuals with less than completed primary education.
} 
declined, but this was more than offset by growth on the intensive margin, which helped to maintain family business's share of income at 19 percent of household income.

Turning to Table A4B, in the urban sector we observe much smaller shifts in the composition of incomes, but there are two important similarities with the rural economy. First, growth in urban incomes is led by the rising wage earnings, which increase as a share of urban incomes from 43 percent to 50 percent. And second, new labor market opportunities are resulting in an exodus from family run businesses. Between 2002 and 2014, the percentage of urban households in this activity declined from 55.6 to 45.7, while the share of total household income from family businesses fell from 31 percent to 27 percent.

\section{A.6 Rural and urban inequality decompositions by income source}

We begin by providing a summary of the distribution of income by sources across quartiles in Tables A5A and A5B for the rural and urban samples respectively. As in Table 5, the quartiles are defined on the basis of nonfood expenditure, $\tilde{c}_{i}$, so the relationships we observe here are akin to the "reduced form" relationship between $\tilde{c}_{i}$ and $y_{i k}$. Looking first at the rural sample in Table A5A, we can see that in 2002, crop income is much more important for the poorest quartile, accounting for 42.6 percent of total income, than for the richest quartile, accounting for only 21.9 percent of total income. In contrast, business income is much more important for the richest quartile as a share of income than for the poorest quartile. Additionally, we can see that wage income is relatively evenly distributed across the quartiles in 2002. By 2014, crop income has dropped in importance for each quartile, but most so for the poorest quartile. The drop in the share of income coming from crops in the lowest quartile has been accompanied with a large rise in the share of wage income within the bottom quartile. While the share of wage income grew across all four quartiles, it grew most for the bottom quartiles as these household shifted out of agriculture in the labor market. In 2014, business income remains unequally distributed, in favour of the rich, among rural households.

For urban households in 2002 (Table A5B), the share of income from each source is more evenly distributed across quartiles than in rural areas. For example, the difference in the share of income coming from businesses is greatest between the 1st and 3rd quartiles at 4.9 percentage points. Wage income, the most important income source in urban areas, is very evenly distributed 
across quartiles. This pattern is generally true in 2014 as well. Again, wage income is very evenly distributed across quartiles as it increased in importance within each quartile. Other income is becoming more unevenly distributed across the quartiles as it increased from 9.8 to 17.9 percentage points for the 4th quartile.

We decompose rural and urban income inequality by income source, mirroring the analysis for the national sample presented in Table 6. The rural decompositions are presented in Table A6A. In 2002, crop income is the largest share of income (0.291). The Shorrocks decomposition, however, indicates that it contributes only 0.154 to overall inequality, and even less when we account for measurement error (0.098). ${ }^{4}$ Wages account for 24 percent of income, and also a much lower share of inequality ( 0.131 by OLS, 0.186 by IV). These two important sources of income are thus relatively equalizing. Business income, on the other hand, is the major culprit for generating inequality, well in excess of its share of income (over one-third of inequality, versus less than twenty percent of household income).

The Gini decomposition underscores the reasons for these patterns. First, crop income has the lowest correlation $\left(R_{k}\right)$ with overall income (i.e., it is evenly distributed across the income distribution). As an income source, it is also the most equally distributed, with the lowest $G_{k}$ of any source of rural income. If we were able to correct $R_{k}$ for measurement error, as we could with the regression-based Shorrocks, crop income would contribute even less than the 16.9 percent share of the overall Gini that we estimate. Business income, on the other hand, is both highly unequally distributed, and also highly correlated with overall income. This is true even when we adjust for measurement error (as seen in the Shorrocks results). Finally, wage income is middling in terms of both its correlation with overall income, and the inequality of wage income itself.

By 2014, the share of crop and sideline income drop considerably, while wages have become much more important. As before, the Shorrocks decomposition suggests that crop income contributes less to inequality than its share of income. While wage income has increased from 0.24 to 0.369 of overall income, its contribution to overall inequality has not increased as rapidly. The story for business income is about the same in 2014 as 2002, although the IV estimate suggests a significant increase in its contribution to inequality. For the Gini decompositions, we see again that crop

\footnotetext{
${ }^{4}$ The endogeneity test strongly rejects the OLS estimates in favor of IV, suggesting that measurement error is a potential factor in biasing the OLS-based Shorrocks decompositions
} 
income has a relatively low correlation with overall income and also that it is more unequally distributed (but note there are more zeroes). Business income is just as correlated with overall income as in 2002, and also just as unequal. Wages are still middling in terms of correlation with overall income. What is remarkable about wage income is that it is relatively equally distributed (it is the least unequal source of income).

That said, as we saw earlier, the rural Gini increased from 0.341 to 0.365 between 2002 and 2014 (an increase of 0.025). Almost all of this is attributable to wage inequality: the share of wages went up as did its correlation with overall income. Offsetting this, wage inequality itself went down, especially as more households moved from zero to positive wage earnings. Access to the labour market, which is generally equalizing, is absolutely critical in the development of overall inequality. Lack of access to wage jobs will hold the lower income households back (e.g., for ethnic minority households).

For urban households, the Shorrocks decomposition identifies wage income as a primary culprit in overall inequality in 2002 (see Table A6B). Note the striking difference between the IV and OLS estimates. This is what we would expect if business income (for example) is measured with error. The OLS procedure exaggerates business' contribution to inequality, while the same measurement error understates the role of wage income. That said, the Shorrocks procedure (with IV) shows that while wage income accounts for 42.9 percent of income, it accounts for 48.8 percent of inequality - not that much out of line with its share of income. Remittance income is also important in generating more inequality than suggested by its share of income. In absolute terms, business income is also disequalizing, though less than its share of income. The Gini procedure also flags wage income as being highly correlated with overall income $\left(R_{k}\right)$, though not especially unequally distributed itself. It thus contributes about as much to inequality as its share (around 40 percent). Given the implications of the Shorrocks IV results for measurement error, we believe that this probably understates the role of wage inequality in overall inequality.

For 2014, wage income rises to 50 percent of total income. Again, the IV-estimated Shorrocks term is higher than the OLS for wage income, suggesting that measurement error leads to an understated role of wage income in overall inequality. The Gini coefficient of wage earnings is actually lower in 2014 than 2002 (0.533 versus 0.590). With rising participation in the labor market, wage income is more prevalent and less unequally distributed, but it is still highly correlated with 
overall income, and thus an important contributor to overall inequality, as are wage earnings via remittances.

Turning to the overall decomposition of the changes between 2002 and 2014, note that the Gini declined from 0.365 to 0.313 , as we discussed earlier. This decline was driven by sharp declines in the disequalizing effects of business income, and especially, remittances. If remittance income alone recovers to previous levels, overall urban inequality could easily increase to previous levels. Wage inequality added little to the Gini, 0.005. 


\section{Appendix B Comparing Household Survey to National Account Growth Rates}

In this appendix we compare the implied annual growth rates of "income" using the VHLSS household-level survey data, with those available from the National Income and Expenditure Accounts. The NIEA data we employ are drawn from the World Bank's "World Development Indicators." Our objective is not to compare the actual levels of income, as the definitions of income differ, as do the data sources. Instead, we wish to determine whether the household and national income data paint similar pictures of growth rates in Vietnam between 2002 and 2014.

In the first two rows of Table B1, we reproduce the mean per capita income estimates for all of Vietnam shown in Table 1 of the main paper, as well as the implied average annual growth rates over the decade. Whether using household income or expenditure (consumption), we estimate real per capita growth rates of 6.9 and 8.0 percent per year. As our first point of comparison, we use the NIEA-based estimate of national household expenditure, divided by overall population and deflated by the CPI so that all values are expressed in thousands of 2012 VND. These numbers line up remarkably well with our VHLSS household income estimates, and are slightly higher than our expenditure estimates. The implied growth rates are remarkably similar to those in the VHLSS, at 6.8 percent. The NIEA estimates therefore line up very well with the household survey data.

We also report per capita GDP, deflated by the GDP deflator. GDP per capita is much higher than household income by definition, as well as differences in measurement. ${ }^{5}$ The implied growth rate is somewhat lower at 5.1 percent. Some of the gap between household and GDP growth rates, however, is driven by differences in deflators. The CPI grew at an annual average of 8.8 percent over this period, well below the 9.8 percent rate of increase of the GDP deflator. Note the very high levels of inflation in the latter part of the decade: Estimates of real growth rate are unavoidably sensitive to the choice of deflator. Also, differences between the CPI and GDP Deflator account for a considerable proportion of the difference between per capita GDP growth and household income/expenditure growth. Especially accounting for differences in the price indices used (CPI versus GDP deflator), therefore, the two data source paint a remarkably similar picture of growth

\footnotetext{
${ }^{5}$ For example, "business income" measures small-scale family enterprises in the VHLSS, whereas the analogous variable in the National Accounts is calculated on the basis of enterprise surveys.
} 
in living standards between 2002 and 2014. See also Bhattacharya (2013) for a discussion of inflation over this time period, which helps contribute to explaining the importance of deflators to the overall picture of growth, as well as the macroeconomic environment in Vietnam more generally. The bottom line is that the basic picture of growth presented in the National Accounts is consistent with that in the VHLSS. 
Table A1: Sample Sizes, Trimmed and Untrimmed Samples

\begin{tabular}{lrrrrrrr}
\hline \hline & 2002 & 2004 & 2006 & 2008 & 2010 & 2012 & 2014 \\
\hline Full Sample Sizes: & & & & & & & \\
Rural & 22,621 & 6,992 & 6,879 & 6,837 & 6,750 & 6,696 & 6,611 \\
Urban & 6,909 & 2,193 & 2,298 & 2,352 & 2,649 & 2,703 & 2,781 \\
\cline { 2 - 8 } Total & 29,530 & 9,185 & 9,177 & 9,189 & 9,399 & 9,399 & 9,392 \\
\cline { 2 - 8 } Trimmed Sample Sizes: & & & & & & \\
Rural & 22,238 & 6,885 & 6,762 & 6,705 & 6,621 & 6,572 & 6,491 \\
Urban & 6,788 & 2,156 & 2,258 & 2,306 & 2,597 & 2,653 & 2,732 \\
\cline { 2 - 7 } Total & 29,026 & 9,041 & 9,020 & 9,011 & 9,218 & 9,225 & 9,223 \\
\hline Notes: This table reports sample sizes for the trimmed and untrimmed samples, \\
broken down by Urban, Rural, and Total samples. \\
\hline \hline
\end{tabular}


Table A2: Core results for untrimmed sample

\begin{tabular}{|c|c|c|c|c|c|c|c|c|}
\hline & 2002 & 2004 & 2006 & 2008 & 2010 & 2012 & 2014 & Delta \\
\hline \multicolumn{9}{|l|}{ Per Capita Income } \\
\hline All Vietnam & 11,461 & 14,144 & 16,117 & 18,686 & 22,407 & 24,057 & 25,703 & $6.7 \%$ \\
\hline Rural & 9,606 & 12,100 & 13,975 & 15,716 & 18,565 & 20,675 & 22,385 & $7.1 \%$ \\
\hline Urban & 17,795 & 20,738 & 23,094 & 26,461 & 31,511 & 32,097 & 32,974 & $5.1 \%$ \\
\hline Ratio (U/R) & 1.85 & 1.71 & 1.65 & 1.68 & 1.70 & 1.55 & 1.47 & -0.38 \\
\hline \multicolumn{9}{|c|}{ Per Capita Consumption } \\
\hline All Vietnam & 9,105 & 11,548 & 11,791 & 13,640 & 22,473 & 22,953 & 23,714 & $8.0 \%$ \\
\hline Rural & 7,306 & 9,154 & 9,666 & 10,842 & 17,322 & 18,680 & 19,463 & $8.2 \%$ \\
\hline Urban & 15,246 & 19,270 & 18,710 & 20,964 & 34,681 & 33,114 & 33,032 & $6.4 \%$ \\
\hline Ratio (U/R) & 2.09 & 2.11 & 1.94 & 1.93 & 2.00 & 1.77 & 1.70 & -0.39 \\
\hline \multicolumn{9}{|l|}{ Inequality } \\
\hline \multicolumn{9}{|l|}{ All Vietnam } \\
\hline Gini (Income) & $\begin{array}{c}0.396 \\
(0.006)\end{array}$ & $\begin{array}{c}0.381 \\
(0.005)\end{array}$ & $\begin{array}{c}0.390 \\
(0.006)\end{array}$ & $\begin{array}{c}0.416 \\
(0.009)\end{array}$ & $\begin{array}{c}0.425 \\
(0.012)\end{array}$ & $\begin{array}{c}0.391 \\
(0.007)\end{array}$ & $\begin{array}{c}0.371 \\
(0.004)\end{array}$ & -0.025 \\
\hline Gini (Consumption) & $\begin{array}{c}0.347 \\
(0.002)\end{array}$ & $\begin{array}{c}0.355 \\
(0.003)\end{array}$ & $\begin{array}{c}0.341 \\
(0.003)\end{array}$ & $\begin{array}{c}0.342 \\
(0.005)\end{array}$ & $\begin{array}{c}0.392 \\
(0.006)\end{array}$ & $\begin{array}{c}0.358 \\
(0.005)\end{array}$ & $\begin{array}{c}0.344 \\
(0.004)\end{array}$ & -0.004 \\
\hline Theil (Income) & $\begin{array}{c}0.338 \\
(0.039)\end{array}$ & $\begin{array}{c}0.274 \\
(0.012)\end{array}$ & $\begin{array}{c}0.293 \\
(0.014)\end{array}$ & $\begin{array}{c}0.373 \\
(0.032)\end{array}$ & $\begin{array}{c}0.401 \\
(0.068)\end{array}$ & $\begin{array}{c}0.298 \\
(0.026)\end{array}$ & $\begin{array}{c}0.250 \\
(0.010)\end{array}$ & -0.088 \\
\hline Theil (Consumption) & $\begin{array}{c}0.219 \\
(0.004)\end{array}$ & $\begin{array}{c}0.224 \\
(0.005)\end{array}$ & $\begin{array}{c}0.203 \\
(0.005)\end{array}$ & $\begin{array}{c}0.209 \\
(0.010)\end{array}$ & $\begin{array}{c}0.292 \\
(0.012)\end{array}$ & $\begin{array}{c}0.232 \\
(0.008)\end{array}$ & $\begin{array}{c}0.211 \\
(0.006)\end{array}$ & -0.008 \\
\hline \multicolumn{9}{|l|}{ Rural } \\
\hline Gini (Income) & $\begin{array}{c}0.357 \\
(0.004)\end{array}$ & $\begin{array}{c}0.357 \\
(0.005)\end{array}$ & $\begin{array}{c}0.373 \\
(0.007)\end{array}$ & $\begin{array}{c}0.393 \\
(0.010)\end{array}$ & $\begin{array}{c}0.406 \\
(0.016)\end{array}$ & $\begin{array}{c}0.383 \\
(0.005)\end{array}$ & $\begin{array}{c}0.377 \\
(0.005)\end{array}$ & 0.020 \\
\hline Gini (Consumption) & $\begin{array}{c}0.277 \\
(0.002)\end{array}$ & $\begin{array}{c}0.290 \\
(0.004)\end{array}$ & $\begin{array}{c}0.293 \\
(0.003)\end{array}$ & $\begin{array}{c}0.282 \\
(0.003)\end{array}$ & $\begin{array}{c}0.332 \\
(0.005)\end{array}$ & $\begin{array}{c}0.318 \\
(0.004)\end{array}$ & $\begin{array}{c}0.309 \\
(0.004)\end{array}$ & 0.032 \\
\hline Theil (Income) & $\begin{array}{c}0.252 \\
(0.011)\end{array}$ & $\begin{array}{c}0.244 \\
(0.013)\end{array}$ & $\begin{array}{c}0.273 \\
(0.017)\end{array}$ & $\begin{array}{c}0.339 \\
(0.041)\end{array}$ & $\begin{array}{c}0.408 \\
(0.100)\end{array}$ & $\begin{array}{c}0.261 \\
(0.010)\end{array}$ & $\begin{array}{c}0.261 \\
(0.017)\end{array}$ & 0.009 \\
\hline Theil (Consumption) & $\begin{array}{c}0.132 \\
(0.002)\end{array}$ & $\begin{array}{c}0.149 \\
(0.005)\end{array}$ & $\begin{array}{c}0.147 \\
(0.004)\end{array}$ & $\begin{array}{c}0.135 \\
(0.003)\end{array}$ & $\begin{array}{c}0.199 \\
(0.011)\end{array}$ & $\begin{array}{c}0.176 \\
(0.006)\end{array}$ & $\begin{array}{c}0.165 \\
(0.006)\end{array}$ & 0.032 \\
\hline \multicolumn{9}{|l|}{ Urban } \\
\hline Gini (Income) & $\begin{array}{c}0.397 \\
(0.014)\end{array}$ & $\begin{array}{c}0.360 \\
(0.010)\end{array}$ & $\begin{array}{c}0.361 \\
(0.009)\end{array}$ & $\begin{array}{c}0.402 \\
(0.015)\end{array}$ & $\begin{array}{c}0.399 \\
(0.012)\end{array}$ & $\begin{array}{c}0.365 \\
(0.017)\end{array}$ & $\begin{array}{c}0.323 \\
(0.006)\end{array}$ & -0.074 \\
\hline Gini (Consumption) & $\begin{array}{c}0.349 \\
(0.003)\end{array}$ & $\begin{array}{c}0.332 \\
(0.006)\end{array}$ & $\begin{array}{c}0.317 \\
(0.006)\end{array}$ & $\begin{array}{c}0.329 \\
(0.008)\end{array}$ & $\begin{array}{c}0.385 \\
(0.010)\end{array}$ & $\begin{array}{c}0.346 \\
(0.009)\end{array}$ & $\begin{array}{c}0.329 \\
(0.006)\end{array}$ & -0.020 \\
\hline Theil (Income) & $\begin{array}{c}0.381 \\
(0.091)\end{array}$ & $\begin{array}{c}0.240 \\
(0.019)\end{array}$ & $\begin{array}{c}0.255 \\
(0.021)\end{array}$ & $\begin{array}{c}0.347 \\
(0.049)\end{array}$ & $\begin{array}{c}0.312 \\
(0.030)\end{array}$ & $\begin{array}{c}0.299 \\
(0.057)\end{array}$ & $\begin{array}{c}0.189 \\
(0.010)\end{array}$ & -0.192 \\
\hline Theil (Consumption) & $\begin{array}{c}0.205 \\
(0.005)\end{array}$ & $\begin{array}{c}0.183 \\
(0.007)\end{array}$ & $\begin{array}{c}0.171 \\
(0.008)\end{array}$ & $\begin{array}{c}0.190 \\
(0.017)\end{array}$ & $\begin{array}{c}0.276 \\
(0.019)\end{array}$ & $\begin{array}{c}0.217 \\
(0.015)\end{array}$ & $\begin{array}{c}0.195 \\
(0.010)\end{array}$ & -0.009 \\
\hline
\end{tabular}

Notes: (1) This table replicates the core results from Tables 1 and 2 for the untrimmed samples (All Vietnam, Rural, and Urban); (2) See the notes to Tables 1 and 2 for further explanations. 
Table A3: Urban/Rural Dimensions of Inequality using Consumption

\begin{tabular}{|c|c|c|c|c|c|c|c|c|}
\hline & 2002 & 2004 & 2006 & 2008 & 2010 & 2012 & 2014 & Delta \\
\hline \multicolumn{9}{|c|}{ Per Capita Consumption Levels } \\
\hline Rural & 7,375 & 9,223 & 9,747 & 10,923 & 17,385 & 18,869 & 19,697 & $8.2 \%$ \\
\hline Urban & 15,375 & 19,490 & 18,971 & 20,920 & 34,700 & 33,136 & 33,146 & $6.4 \%$ \\
\hline Ratio & 2.08 & 2.11 & 1.95 & 1.92 & 2.00 & 1.76 & 1.68 & -0.40 \\
\hline \multicolumn{9}{|c|}{$\begin{array}{l}\text { Consumption Inequality } \\
\text { Rural }\end{array}$} \\
\hline Gini & $\begin{array}{c}0.271 \\
(0.002)\end{array}$ & $\begin{array}{c}0.284 \\
(0.004)\end{array}$ & $\begin{array}{c}0.285 \\
(0.003)\end{array}$ & $\begin{array}{c}0.276 \\
(0.003)\end{array}$ & $\begin{array}{c}0.320 \\
(0.003)\end{array}$ & $\begin{array}{c}0.312 \\
(0.004)\end{array}$ & $\begin{array}{c}0.303 \\
(0.004)\end{array}$ & 0.032 \\
\hline Theil & $\begin{array}{c}0.127 \\
(0.002)\end{array}$ & $\begin{array}{c}0.143 \\
(0.005)\end{array}$ & $\begin{array}{c}0.138 \\
(0.004)\end{array}$ & $\begin{array}{c}0.129 \\
(0.003)\end{array}$ & $\begin{array}{c}0.176 \\
(0.005)\end{array}$ & $\begin{array}{c}0.167 \\
(0.005)\end{array}$ & $\begin{array}{c}0.158 \\
(0.005)\end{array}$ & 0.031 \\
\hline Urban & & & & & & & & \\
\hline Gini & $\begin{array}{c}0.343 \\
(0.004)\end{array}$ & $\begin{array}{c}0.325 \\
(0.006)\end{array}$ & $\begin{array}{c}0.310 \\
(0.006)\end{array}$ & $\begin{array}{c}0.316 \\
(0.006)\end{array}$ & $\begin{array}{c}0.373 \\
(0.008)\end{array}$ & $\begin{array}{c}0.336 \\
(0.006)\end{array}$ & $\begin{array}{c}0.321 \\
(0.007)\end{array}$ & -0.022 \\
\hline Theil & $\begin{array}{c}0.197 \\
(0.005)\end{array}$ & $\begin{array}{c}0.176 \\
(0.007)\end{array}$ & $\begin{array}{c}0.163 \\
(0.007)\end{array}$ & $\begin{array}{c}0.166 \\
(0.007)\end{array}$ & $\begin{array}{c}0.255 \\
(0.013)\end{array}$ & $\begin{array}{c}0.198 \\
(0.013)\end{array}$ & $\begin{array}{c}0.181 \\
(0.009)\end{array}$ & -0.016 \\
\hline
\end{tabular}

Table A4A: The structure of Rural household income

\begin{tabular}{|c|c|c|c|c|c|}
\hline & \multicolumn{3}{|c|}{$\overline{\text { Level }}$} & \multicolumn{2}{|c|}{ Share } \\
\hline & 2002 & 2014 & Growth & 2002 & 2014 \\
\hline Crop income & 2,783 & 4,389 & $3.8 \%$ & $29.1 \%$ & $19.5 \%$ \\
\hline Sideline income & 1,344 & 2,385 & $4.8 \%$ & $14.0 \%$ & $10.6 \%$ \\
\hline Family business & 1,810 & 4,353 & $7.3 \%$ & $18.9 \%$ & $19.3 \%$ \\
\hline Wages & 2,295 & 8,320 & $10.7 \%$ & $24.0 \%$ & $36.9 \%$ \\
\hline Remittances & 826 & 1,649 & $5.8 \%$ & $8.6 \%$ & $7.3 \%$ \\
\hline Other income & 510 & 1,431 & $8.6 \%$ & $5.3 \%$ & $6.4 \%$ \\
\hline \multirow[t]{3}{*}{ Total } & 9,568 & 22,527 & $7.1 \%$ & & \\
\hline & \multicolumn{3}{|c|}{ Conditional on Positive } & \multicolumn{2}{|c|}{ Participation } \\
\hline & 2002 & 2014 & Growth & 2002 & 2014 \\
\hline Crop income & 3,249 & 5,609 & 4.5 & 85.7 & 78.8 \\
\hline Sideline income & 1,662 & 3,730 & 6.7 & 81.3 & 64.6 \\
\hline Family business & 4,927 & 14,282 & 8.9 & 36.7 & 30.5 \\
\hline Wages & 4,076 & 12,272 & 9.2 & 56.3 & 67.8 \\
\hline Remittances & 1,046 & 1,924 & 5.1 & 79.0 & 85.7 \\
\hline Other income & 1,367 & 3,321 & 7.4 & 37.3 & 43.1 \\
\hline \multicolumn{6}{|c|}{$\begin{array}{l}\text { Notes: (1) This table reports mean per capita Rural household income } \\
\text { by source, in constant } 2012 \text { VND; (2) In the top panel, we show the } \\
\text { unconditional means, the implied annual percentage-rate growth of rate } \\
\text { between } 2002 \text { and } 2014 \text {, and the percentage share of total income by } \\
\text { source; (3) In the bottom panel, we report average income by source } \\
\text { conditional on positive, the implied annual percentage-rate growth of } \\
\text { rate between } 2002 \text { and } 2014 \text {, and the percentage of households with } \\
\text { positive earnings for that source (i.e., the participation rate). }\end{array}$} \\
\hline
\end{tabular}


Table A4B: The structure of Urban household income

\begin{tabular}{lrrrrrr}
\hline \hline & \multicolumn{3}{c}{ Level } & & \multicolumn{3}{c}{ Share } \\
\cline { 2 - 3 } \cline { 6 - 7 } & 2002 & 2014 & Growth & & 2002 & 2014 \\
\hline Crop income & 603 & 1,308 & $6.5 \%$ & & $3.5 \%$ & $4.0 \%$ \\
Sideline income & 591 & 539 & $-0.8 \%$ & & $3.4 \%$ & $1.6 \%$ \\
Family business & 5,310 & 8,802 & $4.2 \%$ & & $30.7 \%$ & $26.6 \%$ \\
Wages & 7,416 & 16,487 & $6.7 \%$ & & $42.9 \%$ & $49.8 \%$ \\
Remittances & 1,903 & 1,915 & $0.1 \%$ & & $11.0 \%$ & $5.8 \%$ \\
Other income & 1,468 & 4,027 & $8.4 \%$ & & $8.5 \%$ & $12.2 \%$ \\
\hline Total & 17,291 & 33,079 & $5.4 \%$ & & \\
\hline & \multicolumn{3}{c}{ Conditional on } & & & \multicolumn{2}{c}{} \\
\cline { 2 - 3 } & 2002 & 2014 & Growth & & 2002 & 2014 \\
\hline Crop income & 2,635 & 5,968 & 6.8 & & 23.0 & 21.9 \\
Sideline income & 2,537 & 3,372 & 2.4 & & 23.4 & 16.0 \\
Family business & 9,551 & 19,247 & 5.8 & & 55.6 & 45.7 \\
Wages & 10,319 & 21,665 & 6.2 & & 71.9 & 76.1 \\
Remittances & 2,478 & 2,173 & -1.1 & & 76.8 & 88.1 \\
Other income & 3,372 & 8,133 & 7.3 & & 43.5 & 49.5 \\
\hline
\end{tabular}

Notes: (1) This table reports mean per capita Urban household income by source, in constant $2012 \mathrm{VND}$; (2) In the top panel, we show the unconditional means, the implied annual percentage-rate growth of rate between 2002 and 2014, and the percentage share of total income by source; (3) In the bottom panel, we report average income by source conditional on positive, the implied annual percentage-rate growth of rate between 2002 and 2014, and the percentage of households with positive earnings for that source (i.e., the participation rate). 
Table A5A: Composition of Income by Quartile Group (Rural)

\begin{tabular}{|c|c|c|c|c|c|}
\hline \multirow[t]{2}{*}{2002} & \multicolumn{4}{|c|}{ Quartile } & \multirow[b]{2}{*}{ Q1-Q4 } \\
\hline & 1 & 2 & 3 & 4 & \\
\hline Crop income & 42.6 & 33.3 & 30.8 & 21.9 & 20.7 \\
\hline Sideline income & 16.0 & 15.4 & 14.7 & 12.4 & 3.6 \\
\hline Family business & 8.1 & 13.6 & 18.6 & 24.9 & -16.8 \\
\hline Wages & 24.0 & 27.0 & 24.3 & 22.4 & 1.6 \\
\hline Remittances & 5.2 & 5.9 & 6.6 & 12.2 & -6.9 \\
\hline Other income & 4.0 & 4.8 & 5.0 & 6.2 & -2.1 \\
\hline \multirow[t]{2}{*}{2014} & \multicolumn{4}{|c|}{ Quartile } & \\
\hline & 1 & 2 & 3 & 4 & Q1-Q4 \\
\hline Crop income & 29.0 & 21.3 & 18.0 & 16.7 & 12.3 \\
\hline Sideline income & 11.8 & 11.9 & 10.7 & 9.5 & 2.4 \\
\hline Family business & 6.6 & 13.0 & 20.8 & 25.3 & -18.6 \\
\hline Wages & 40.3 & 42.0 & 38.5 & 32.3 & 8.0 \\
\hline Remittances & 6.1 & 6.6 & 6.5 & 8.6 & -2.5 \\
\hline Other income & 6.0 & 5.1 & 5.5 & 7.7 & -1.7 \\
\hline
\end{tabular}

Notes: (1) This table reports the average share of income by source by quartile group; (2) Quartiles are calculated in the basis of household per capita nonfood consumption; (3) The final column provides the difference in percentages of income from a given source between the lowest (Q1) and highest (Q4) quartile group.

Table A5B: Composition of Income by Quartile Group (Urban)

\begin{tabular}{|c|c|c|c|c|c|}
\hline \multirow[t]{2}{*}{2002} & \multicolumn{4}{|c|}{ Quartile } & \multirow[b]{2}{*}{ Q1-Q4 } \\
\hline & 1 & 2 & 3 & 4 & \\
\hline Crop income & 10.2 & 5.4 & 2.5 & 1.5 & 8.8 \\
\hline Sideline income & 5.8 & 4.5 & 4.1 & 1.9 & 3.9 \\
\hline Family business & 28.8 & 31.9 & 33.7 & 29.1 & -0.3 \\
\hline Wages & 41.9 & 41.9 & 41.5 & 44.3 & -2.4 \\
\hline Remittances & 6.6 & 8.4 & 10.8 & 13.4 & -6.8 \\
\hline Other income & 6.7 & 7.9 & 7.4 & 9.8 & -3.2 \\
\hline \multirow[t]{2}{*}{2014} & \multicolumn{4}{|c|}{ Quartile } & \\
\hline & 1 & 2 & 3 & 4 & Q1-Q4 \\
\hline Crop income & 8.5 & 6.3 & 4.0 & 1.0 & 7.5 \\
\hline Sideline income & 11.8 & 2.0 & 1.2 & 0.5 & 11.3 \\
\hline Family business & 25.2 & 27.9 & 29.4 & 24.6 & 0.6 \\
\hline Wages & 50.3 & 49.7 & 49.5 & 50.0 & 0.3 \\
\hline Remittances & 5.2 & 5.8 & 6.0 & 5.9 & -0.6 \\
\hline Other income & 6.0 & 8.3 & 10.0 & 17.9 & -12.0 \\
\hline \multicolumn{6}{|c|}{$\begin{array}{l}\text { Notes: (1) This table reports the average share of income by source by quartile } \\
\text { group; (2) Quartiles are calculated in the basis of household per capita non- } \\
\text { food consumption; ( } 3 \text { ) The final column provides the difference in percentages } \\
\text { of income from a given source between the lowest (Q1) and highest (Q4) quartile } \\
\text { group. }\end{array}$} \\
\hline
\end{tabular}


Table A6A: Decomposing Rural Income Inequality by Source of Income

\begin{tabular}{|c|c|c|c|c|c|c|c|c|}
\hline & \multicolumn{7}{|c|}{2002} & \\
\hline & \multirow[b]{2}{*}{$W_{k}$} & \multicolumn{2}{|c|}{ Shorrocks } & \multicolumn{4}{|c|}{ Gini } & \\
\hline & & OLS & IV & $R_{k}$ & $G_{k}$ & Absolute & Relative & \\
\hline \multirow[t]{2}{*}{ Crop income } & 0.291 & 0.154 & 0.098 & 0.371 & 0.534 & 0.058 & 0.169 & \\
\hline & & $(0.015)$ & $(0.013)$ & $(0.017)$ & $(0.007)$ & $(0.004)$ & $(0.011)$ & \\
\hline Sideline income & 0.140 & $\begin{array}{c}0.157 \\
(0.020)\end{array}$ & $\begin{array}{c}0.095 \\
(0.014)\end{array}$ & $\begin{array}{c}0.456 \\
(0.020)\end{array}$ & $\begin{array}{c}0.690 \\
(0.008)\end{array}$ & $\begin{array}{c}0.044 \\
(0.004)\end{array}$ & $\begin{array}{c}0.130 \\
(0.010)\end{array}$ & \\
\hline Family business & 0.189 & $\begin{array}{c}0.350 \\
(0.023)\end{array}$ & $\begin{array}{c}0.336 \\
(0.020)\end{array}$ & $\begin{array}{c}0.638 \\
(0.011)\end{array}$ & $\begin{array}{c}0.837 \\
(0.004)\end{array}$ & $\begin{array}{c}0.101 \\
(0.004)\end{array}$ & $\begin{array}{c}0.296 \\
(0.012)\end{array}$ & \\
\hline Wages & 0.240 & $\begin{array}{c}0.131 \\
(0.010)\end{array}$ & $\begin{array}{c}0.186 \\
(0.014)\end{array}$ & $\begin{array}{c}0.459 \\
(0.013)\end{array}$ & $\begin{array}{c}0.694 \\
(0.004)\end{array}$ & $\begin{array}{c}0.077 \\
(0.003)\end{array}$ & $\begin{array}{c}0.225 \\
(0.009)\end{array}$ & \\
\hline Remittances & 0.086 & $\begin{array}{c}0.153 \\
(0.013)\end{array}$ & $\begin{array}{c}0.216 \\
(0.012)\end{array}$ & $\begin{array}{c}0.582 \\
(0.013)\end{array}$ & $\begin{array}{c}0.812 \\
(0.004)\end{array}$ & $\begin{array}{c}0.041 \\
(0.002)\end{array}$ & $\begin{array}{c}0.120 \\
(0.006)\end{array}$ & \\
\hline Other income & 0.053 & $\begin{array}{c}0.054 \\
(0.007)\end{array}$ & $\begin{array}{c}0.070 \\
(0.006)\end{array}$ & $\begin{array}{c}0.439 \\
(0.013)\end{array}$ & $\begin{array}{l}0.875 \\
(0.003)\end{array}$ & $\begin{array}{c}0.020 \\
(0.001)\end{array}$ & $\begin{array}{c}0.060 \\
(0.003)\end{array}$ & \\
\hline \multirow[t]{4}{*}{ Total } & & & & & & $\begin{array}{c}0.341 \\
(0.003)\end{array}$ & 1.000 & \multirow{4}{*}{ Delta } \\
\hline & \multicolumn{7}{|c|}{2014} & \\
\hline & & Shol & ocks & & & ini & & \\
\hline & $W_{k}$ & OLS & IV & $R_{k}$ & $G_{k}$ & Absolute & Relative & \\
\hline Crop income & 0.195 & $\begin{array}{c}0.144 \\
(0.026)\end{array}$ & $\begin{array}{c}0.064 \\
(0.052)\end{array}$ & $\begin{array}{c}0.360 \\
(0.025)\end{array}$ & $\begin{array}{c}0.684 \\
(0.013)\end{array}$ & $\begin{array}{c}0.048 \\
(0.005)\end{array}$ & $\begin{array}{c}0.131 \\
(0.012)\end{array}$ & -0.010 \\
\hline Sideline income & 0.106 & $\begin{array}{c}0.175 \\
(0.031)\end{array}$ & $\begin{array}{c}0.055 \\
(0.014)\end{array}$ & $\begin{array}{c}0.453 \\
(0.026)\end{array}$ & $\begin{array}{c}0.837 \\
(0.010)\end{array}$ & $\begin{array}{c}0.040 \\
(0.004)\end{array}$ & $\begin{array}{c}0.110 \\
(0.011)\end{array}$ & -0.004 \\
\hline Family business & 0.193 & $\begin{array}{c}0.362 \\
(0.044)\end{array}$ & $\begin{array}{c}0.446 \\
(0.035)\end{array}$ & $\begin{array}{c}0.648 \\
(0.017)\end{array}$ & $\begin{array}{c}0.857 \\
(0.005)\end{array}$ & $\begin{array}{c}0.107 \\
(0.006)\end{array}$ & $\begin{array}{c}0.294 \\
(0.016)\end{array}$ & 0.006 \\
\hline Wages & 0.369 & $\begin{array}{c}0.179 \\
(0.019)\end{array}$ & $\begin{array}{c}0.213 \\
(0.026)\end{array}$ & $\begin{array}{c}0.520 \\
(0.014)\end{array}$ & $\begin{array}{c}0.617 \\
(0.006)\end{array}$ & $\begin{array}{c}0.119 \\
(0.005)\end{array}$ & $\begin{array}{c}0.325 \\
(0.015)\end{array}$ & 0.042 \\
\hline Remittances & 0.073 & $\begin{array}{c}0.076 \\
(0.015)\end{array}$ & $\begin{array}{c}0.111 \\
(0.014)\end{array}$ & $\begin{array}{c}0.435 \\
(0.023)\end{array}$ & $\begin{array}{c}0.813 \\
(0.006)\end{array}$ & $\begin{array}{c}0.026 \\
(0.002)\end{array}$ & $\begin{array}{c}0.071 \\
(0.006)\end{array}$ & -0.015 \\
\hline Other income & 0.064 & $\begin{array}{c}0.063 \\
(0.009)\end{array}$ & $\begin{array}{c}0.112 \\
(0.016)\end{array}$ & $\begin{array}{c}0.442 \\
(0.020)\end{array}$ & $\begin{array}{c}0.897 \\
(0.003)\end{array}$ & $\begin{array}{c}0.025 \\
(0.002)\end{array}$ & $\begin{array}{c}0.069 \\
(0.005)\end{array}$ & 0.005 \\
\hline Total & & & & & & $\begin{array}{c}0.365 \\
(0.005)\end{array}$ & 1.000 & 0.025 \\
\hline
\end{tabular}

Notes: (1) This table reports the decompositions of Rural income inequality by source for 2002 and 2014; (2) The Shorrocks decompositions are estimated by OLS, and IV (using non-food consumption as an instrument); (3) The Gini decompositions report $R_{k}$ (The Gini correlation), $G_{k}$ (The Gini of income source $k$ ), as well as the combined absolute and relative contributions of income source $k$ to the Gini coefficient of total income; (4) "Delta" is the change in the absolute contribution of income source $k$ to inequality in 2014 and 2002; (5) Standard errors in parentheses; (6) Gini decomposition estimated using DASP (Abdelkrim and Duclos (2007)). 
Table A6B: Decomposing Urban Income Inequality by Source of Income

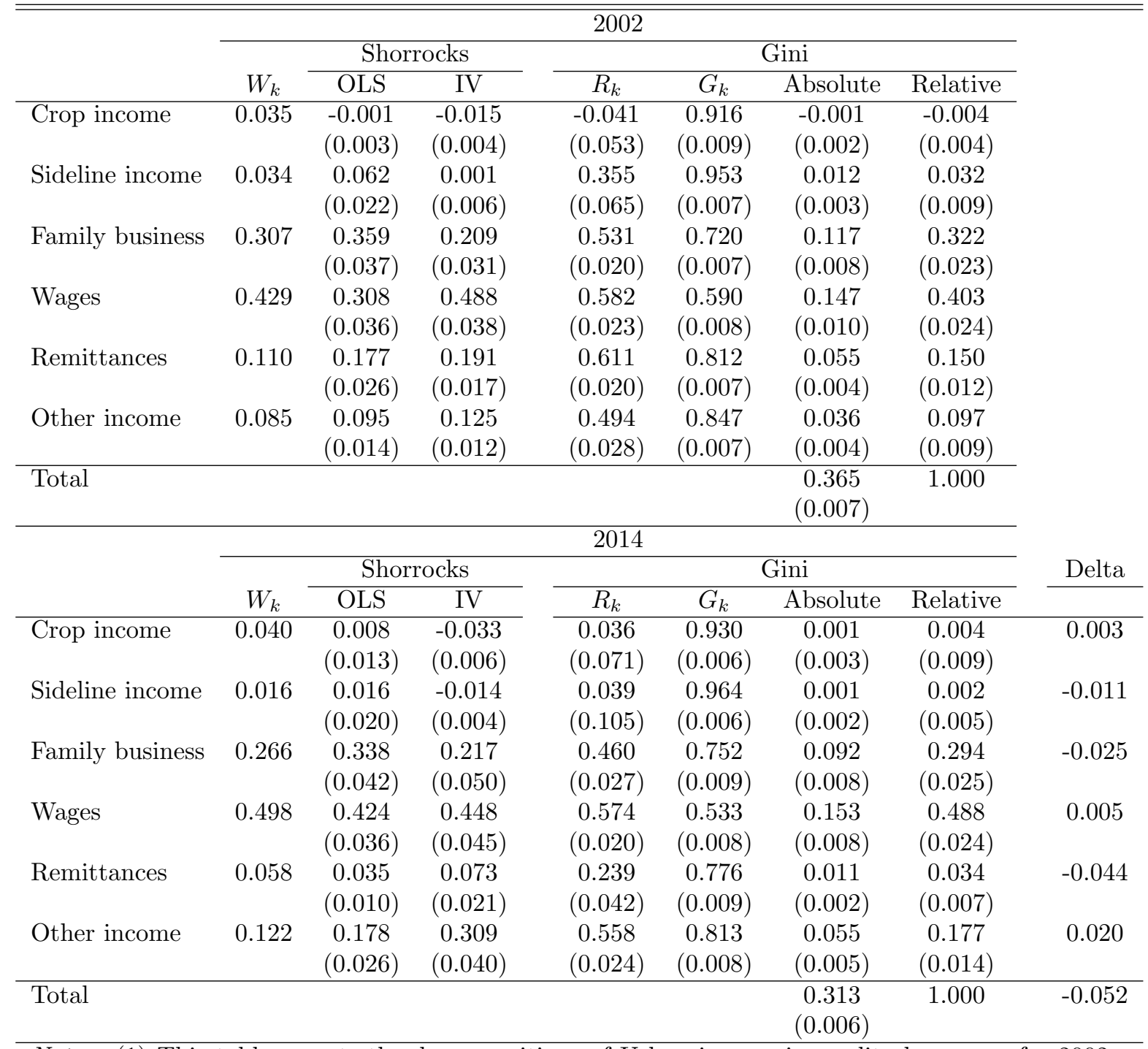

Notes: (1) This table reports the decompositions of Urban income inequality by source for 2002 and 2014; (2) The Shorrocks decompositions are estimated by OLS, and IV (using non-food consumption as an instrument); (3) The Gini decompositions report $R_{k}$ (The Gini correlation), $G_{k}$ (The Gini of income source $k$ ), as well as the combined absolute and relative contributions of income source $k$ to the Gini coefficient of total income; (4) "Delta" is the change in the absolute contribution of income source $k$ to inequality in 2014 and 2002; (5) Standard errors in parentheses; (6) Gini decomposition estimated using DASP (Abdelkrim and Duclos (2007)). 
Figure A1A: Rural Income Levels and and Income Growth by Percentile

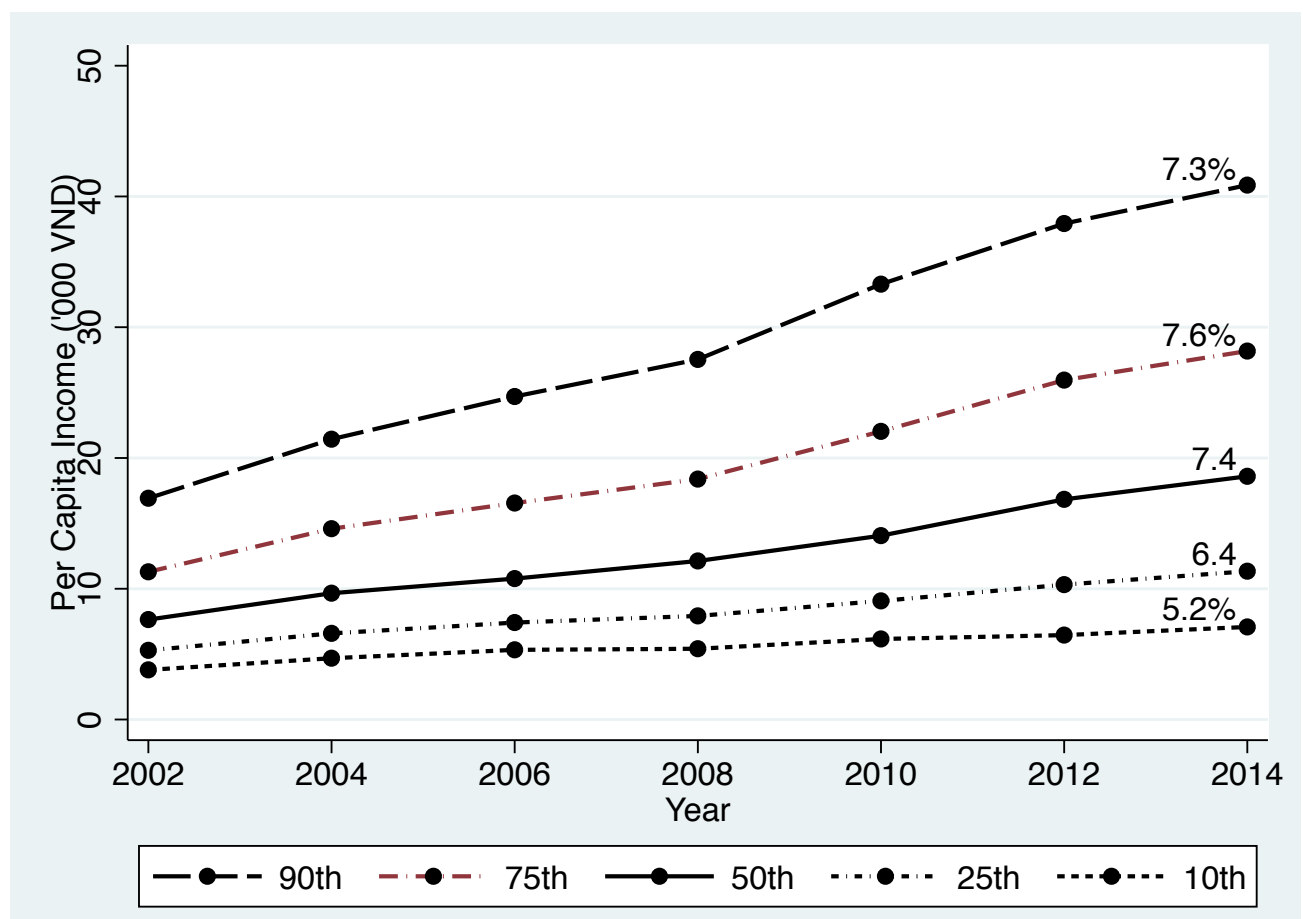

Notes: This figure reports average household per capita income by percentile for Rural households. Beside each line, we report the average growth rate between 2002 and 2014 for that percentile. 
Figure A1B: Urban Income Levels and Income Growth by Percentile

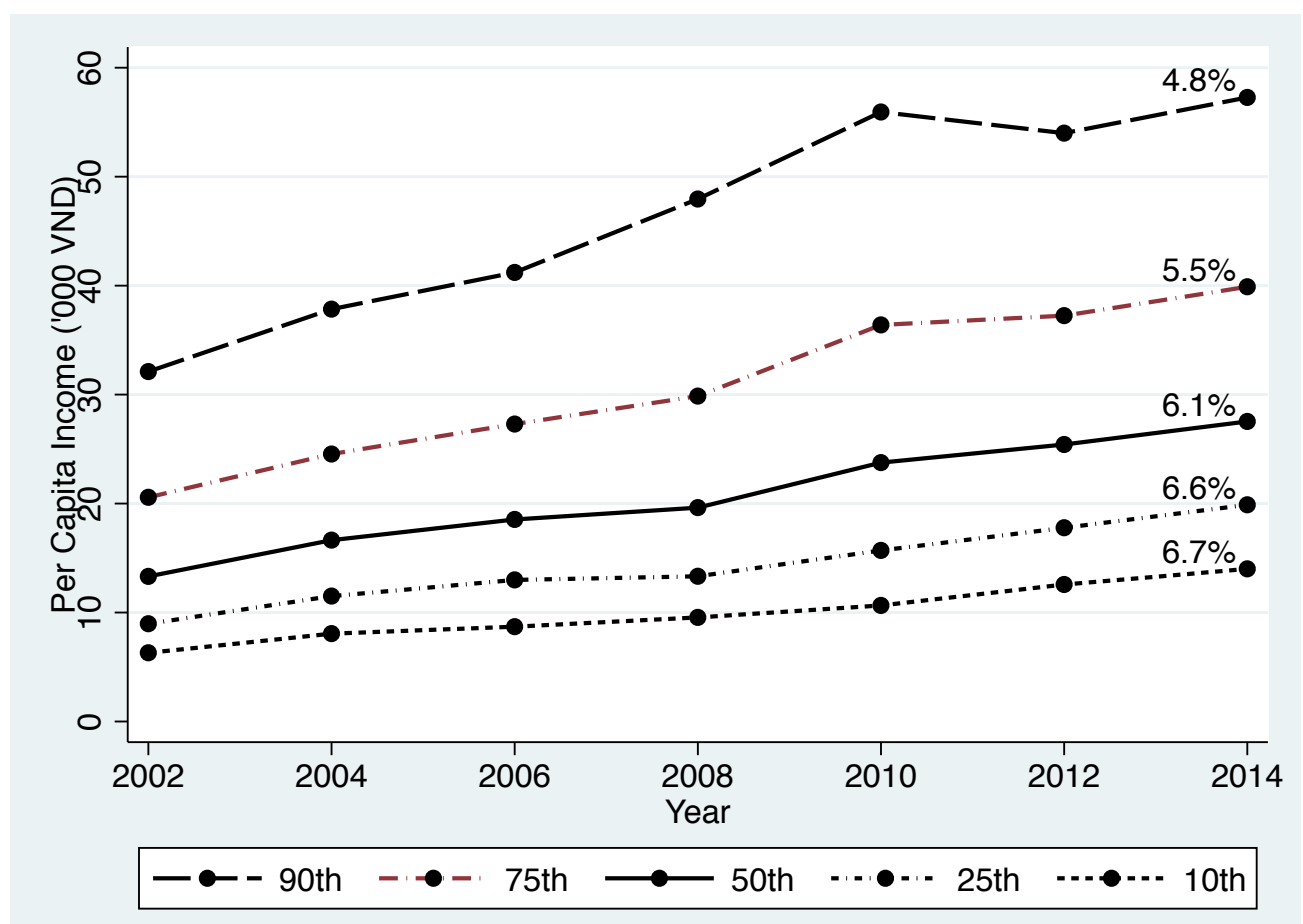

Notes: This figure reports average household per capita income by percentile for Urban households. Beside each line, we report the average growth rate between 2002 and 2014 for that percentile.

Figure A2A: Lorenz Curves of Rural Income per Capita, 2002 and 2014

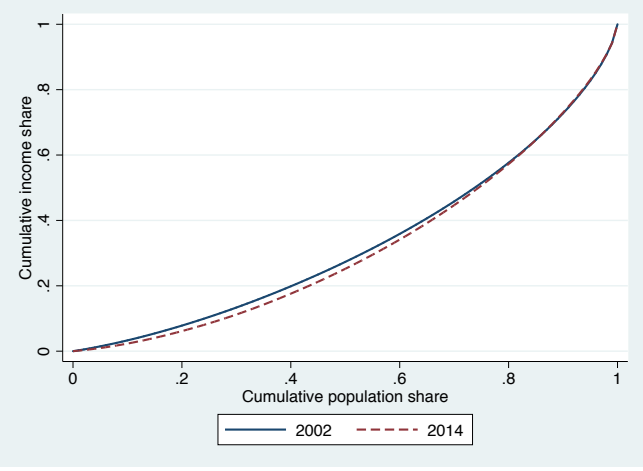

(a) Lorenz curves

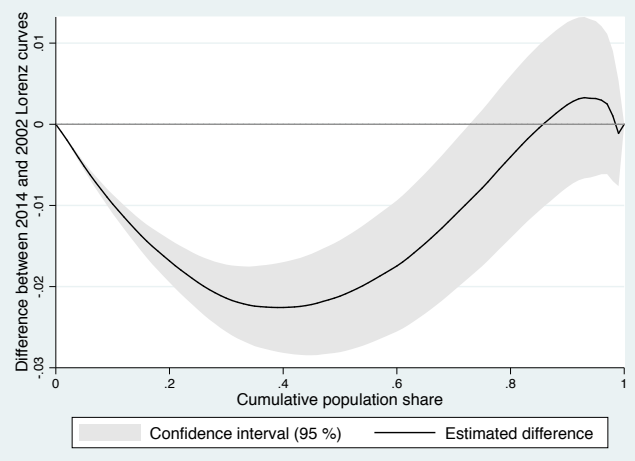

(b) Difference in Lorenz: 2014 - 2002

Notes: These figures show the Lorenz curves for Rural household per capita income in 2002 and 2014 . Panel (a) shows the Lorenz curves themselves, while panel (b) shows the 95\% confidence intervals for the differences between the 2014 and 2002 Lorenz curves. Figures created using DASP (Abdelkrim and Duclos (2007)). 
Figure A2B: Lorenz Curves of Urban Income per Capita, 2002 and 2014

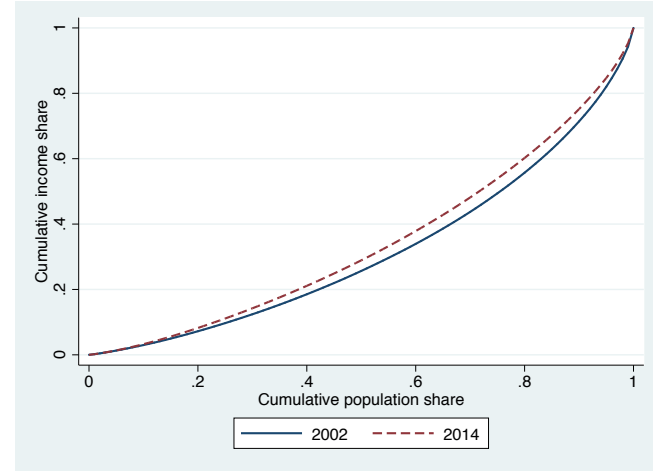

(a) Lorenz curves

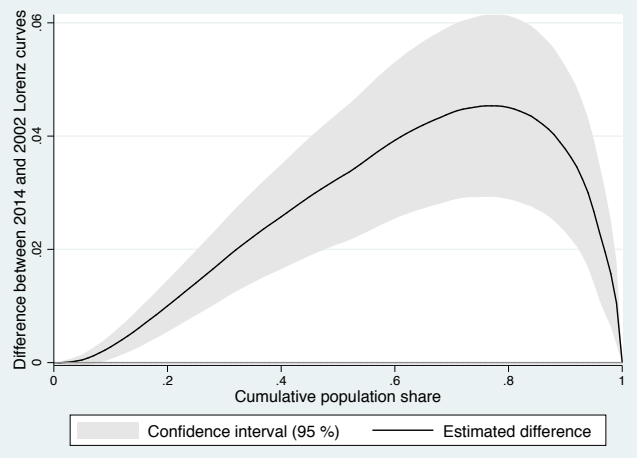

(b) Difference in Lorenz: 2014 - 2002

Notes: These figures show the Lorenz curves for Urban household per capita income in 2002 and 2014. Panel (a) shows the Lorenz curves themselves, while panel (b) shows the 95\% confidence intervals for the differences between the 2014 and 2002 Lorenz curves. Figures created using DASP (Abdelkrim and Duclos (2007)). 
Table B1: Comparing VHLSS to Aggregate Data

\begin{tabular}{lcccccccc}
\hline \hline Variable and data source & 2002 & 2004 & 2006 & 2008 & 2010 & 2012 & 2014 & Growth \\
\hline VHLSS & & & & & & & & \\
Per capita income & 11,318 & 14,166 & 16,074 & 18,257 & 21,790 & 23,992 & 25,843 & $6.9 \%$ \\
Per capita expenditure & 9,188 & 11,648 & 11,913 & 13,682 & 22,521 & 23,098 & 23,923 & $8.0 \%$ \\
& & & & & & & & \\
& & & & & & & & \\
National Income and Expenditure Accounts & & & & & \\
Per capita household expenditure & 11,409 & 13,372 & 16,686 & 20,302 & 21,391 & 23,580 & 25,743 & $6.8 \%$ \\
Per capita GDP & 21,731 & 24,398 & 27,439 & 30,399 & 33,388 & 36,559 & 39,966 & $5.1 \%$ \\
CPI & 38.4 & 42.7 & 49.7 & 66.3 & 77.2 & 100.0 & 110.9 & $8.8 \%$ \\
GDP Deflator & 33.5 & 39.2 & 46.4 & 62.5 & 74.3 & 100.0 & 108.6 & $9.8 \%$ \\
\hline Notes: (1) This table reports estimates of household income and expenditure from the VHLSS surveys, as well \\
as the National Income and Expenditure Accounts (NIEA). We also report two price indices, the CPI, and \\
the GDP Deflator; (2) The VHLSS means are the same as those reported in Table 1; (3) The NIEA series are \\
as follows: i) "Final Household Expenditure" per capita, expressed in 2012 VND using the CPI as deflator; \\
ii) GDP per capita, expressed in 2012 VND using the GDP deflator; iii) The CPI, with 2012 as base year; \\
and iv) The GDP Deflator, with 2012 as base year; (4) Source: http://data.worldbank.org/data-catalog/world- \\
development-indicators, accessed March 10, 2016; (5) "Growth" is average annualized growth between 2002 and \\
2014.
\end{tabular}

